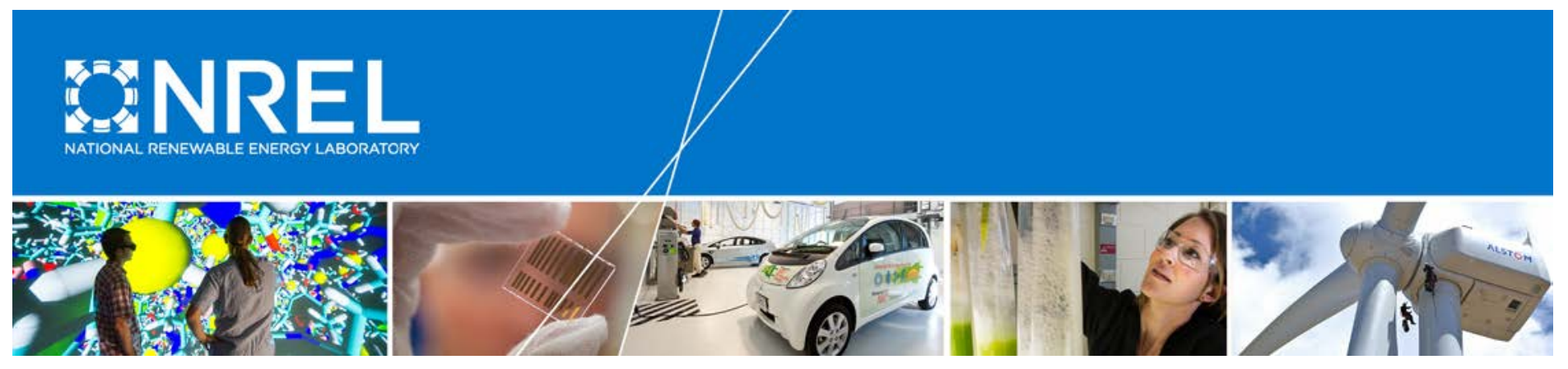

\title{
U.S. Solar Photovoltaic System Cost Benchmark: Q1 2016
}

Ran Fu, Donald Chung, Travis Lowder, David Feldman, Kristen Ardani, and Robert Margolis National Renewable Energy Laboratory (NREL)

NREL is a national laboratory of the U.S. Department of Energy Office of Energy Efficiency \& Renewable Energy Operated by the Alliance for Sustainable Energy, LLC

This report is available at no cost from the National Renewable Energy Laboratory (NREL) at www.nrel.gov/publications.

Technical Report

NREL/TP-6A20-66532

September 2016 


\section{U.S. Solar Photovoltaic System Cost Benchmark: Q1 2016}

Ran Fu, Donald Chung, Travis Lowder, David Feldman, Kristen Ardani, and Robert Margolis National Renewable Energy Laboratory (NREL)

Prepared under Task No. ST6T.0510
National Renewable Energy Laboratory 15013 Denver West Parkway Golden, CO 80401

303-275-3000 • www.nrel.gov
NREL is a national laboratory of the U.S. Department of Energy Office of Energy Efficiency \& Renewable Energy Operated by the Alliance for Sustainable Energy, LLC

This report is available at no cost from the National Renewable Energy Laboratory (NREL) at www.nrel.gov/publications.

\section{Technical Report}

NREL/TP-6A20-66532

September 2016

Contract No. DE-AC36-08G028308 


\section{NOTICE}

This report was prepared as an account of work sponsored by an agency of the United States government. Neither the United States government nor any agency thereof, nor any of their employees, makes any warranty, express or implied, or assumes any legal liability or responsibility for the accuracy, completeness, or usefulness of any information, apparatus, product, or process disclosed, or represents that its use would not infringe privately owned rights. Reference herein to any specific commercial product, process, or service by trade name, trademark, manufacturer, or otherwise does not necessarily constitute or imply its endorsement, recommendation, or favoring by the United States government or any agency thereof. The views and opinions of authors expressed herein do not necessarily state or reflect those of the United States government or any agency thereof.

This report is available at no cost from the National Renewable Energy Laboratory (NREL) at www.nrel.gov/publications.

Available electronically at SciTech Connect http:/www.osti.gov/scitech

Available for a processing fee to U.S. Department of Energy and its contractors, in paper, from:

U.S. Department of Energy

Office of Scientific and Technical Information

P.O. Box 62

Oak Ridge, TN 37831-0062

OSTI http://www.osti.gov

Phone: 865.576.8401

Fax: 865.576.5728

Email: reports@osti.gov

Available for sale to the public, in paper, from:

U.S. Department of Commerce

National Technical Information Service

5301 Shawnee Road

Alexandria, VA 22312

NTIS http://www.ntis.gov

Phone: 800.553 .6847 or 703.605 .6000

Fax: 703.605.6900

Email: orders@ntis.gov 


\section{List of Acronyms}

$\mathrm{AC}$

ASP

BOS

DC

EPC

FICA

LCOE

MLPE

NEM

NREL

PII

PV

Q

SAM

SG\&A

USD

$\mathrm{Vdc}$

Wac

$\mathrm{Wdc}$ alternating current

average selling price

balance of system

direct current

engineering, procurement, and construction

Federal Insurance Contributions Act

levelized cost of energy

module-level power electronics

net energy metering

National Renewable Energy Laboratory

permitting, inspection, and interconnection

photovoltaic(s)

quarter

System Advisor Model

selling, general, and administrative

U.S. dollars

volts direct current

watts alternating current

watts direct current 


\section{Executive Summary}

This report benchmarks U.S. solar photovoltaic (PV) system installed costs as of the first quarter of 2016 (Q1 2016). We use a bottom-up methodology, accounting for all system and projectdevelopment costs incurred during the installation, to model the costs for residential, commercial, and utility-scale systems. In general, we attempt to model the typical installation techniques and business operations from an installed-cost perspective. Costs are represented from the perspective of the developer/installer; thus, all hardware costs represent the price at which components are purchased by the developer/installer. Importantly, the benchmark this year (2016) also represents the sales price paid to the installer; therefore, it includes profit in the cost of the hardware, ${ }^{1}$ and the profit the installer/developer receives, as a separate cost category. However, it does not include any additional net profit, such as a developer fee or price gross-up, which are common in the marketplace. We adopt this approach owing to the wide variation in developer profits in all three sectors, where project pricing is highly dependent on region and project specifics such as local retail electricity rate structures, local rebate and incentive structures, competitive environment, and overall project or deal structures. Finally, our benchmarks are national averages weighted by state installed capacities. Table ES-1 summarizes benchmark assumptions as well as comparisons of previous National Renewable Energy Laboratory (NREL) benchmarking efforts (2009-2015) and the benchmarking in this report.

Table ES-1. Benchmark and Model Change Summary

\begin{tabular}{lll}
\hline Unit & Description & \\
\hline Values & 2016 U.S. dollars (USD) & \\
\hline System Sizes & $\begin{array}{l}\text { In direct current (DC) terms; inverter prices are converted by DC-to-alternating } \\
\text { current (AC) ratios }\end{array}$ & Size Range \\
\hline PV Sector & Description & 3-10 kW \\
\hline Residential & Residential rooftop systems & $10 \mathrm{~kW}-2 \mathrm{MW}$ \\
\hline Commercial & Commercial rooftop systems, ballasted racking & $>2 \mathrm{MW}$ \\
\hline Utility-scale & Ground-mounted systems, fixed-tilt and one-axis tracker & \\
\hline
\end{tabular}

Based on our bottom-up modeling, the Q1 2016 PV cost benchmarks are \$2.93 per watt DC (Wdc) for residential systems, $\$ 2.13 / \mathrm{Wdc}$ for commercial systems, $\$ 1.42 / \mathrm{Wdc}$ (or $\$ 1.99$ per watt $\mathrm{AC}[\mathrm{Wac}]$ ) for fixed-tilt utility-scale systems, and $\$ 1.49 / \mathrm{Wdc}$ (or $\$ 1.79 / \mathrm{Wac}$ ) for one-axis-

\footnotetext{
${ }^{1}$ Profit is one of the differentiators between "cost" (aggregated expenses incurred by a developer/installer to build a system) and "price" (what the end user pays for a system).
} 
tracking utility-scale systems. ${ }^{2}$ Overall, modeled PV installed costs continued to decline in Q1 2016 for all three sectors.

Figure ES-1 puts our Q1 2016 benchmark results in context with the results of previous NREL benchmarking analyses. When comparing the results across this period, note the following:

1. Values are inflation adjusted using the Consumer Price Index. Thus, historical values from our models are adjusted and presented as real USD instead of nominal USD.

2. Cost categories are aggregated for comparison purposes. For instance, "Soft Costs - Others" represents permitting, inspection, and interconnection; land acquisition; sales tax; and engineering, procurement, and construction (EPC)/developer overhead and net profit. ${ }^{3}$

3. The large difference between Q1 2015 and Q1 2016 in the utility-scale sector is caused by amplifying economies-of-scale impacts on EPC contractor and developer costs. The changes between Q1 2015 and Q1 2016 are presented in Table ES-2. ${ }^{4}$

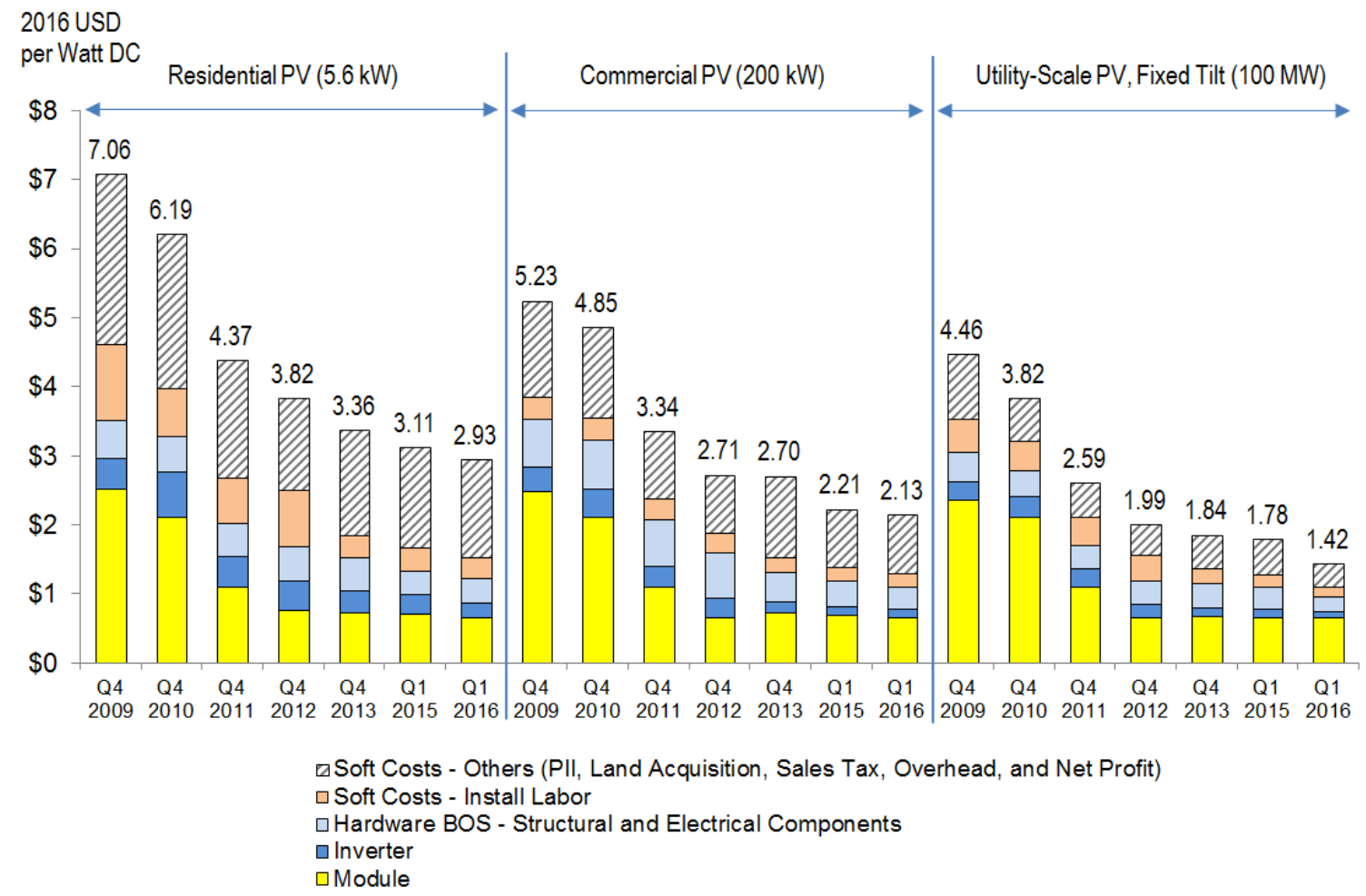

Figure ES-1. NREL PV system cost benchmark summary (inflation adjusted), Q4 2009-Q1 2016

\footnotetext{
${ }^{2}$ While the Q1 2016 benchmark cost for fixed-tilt utility-scale systems is lower than it is for one-axis-tracking systems in Wdc, it is higher in Wac. This is due to the difference in assumed inverter-loading ratios (see Section 2.5).

${ }^{3}$ System cost categories in this report differ from previously published material, beyond inflation adjustments, to delineate profit from overhead for installers and integrators. Also, profit is added to the Q1 2015 commercial benchmark price; thus, it is $\$ 0.06 / \mathrm{W}$ higher than it is in the 2015 publication ( $\$ 0.05 / \mathrm{W}$ profit; $\$ 0.01 / \mathrm{W}$ inflation).

${ }^{4}$ The Q1 2015 (Chung et al. 2015) and Q1 2016 cost benchmarks reported in Figure ES-1 represent national averages, state-weighted by the previous year's state installation by market segment. Therefore, the benchmarks are affected each year by where PV system installations have occurred.
} 
Table ES-2. Q1 2016 NREL PV System Cost Benchmark Change (USD/Wdc)

\begin{tabular}{|c|c|c|c|c|}
\hline Sector & $\begin{array}{l}\text { (1) Difference from } \\
\text { Q1 } 2015 \text { to Q1 } 2016 \\
\text { (2016 USD/Wdc) } \\
(1)=(2)+(3)\end{array}$ & $\begin{array}{l}\text { (2) Year-to-Year } \\
\text { Nominal Cost } \\
\text { Decline }\end{array}$ & $\begin{array}{l}\text { (3) Inflation } \\
\text { Impact }\end{array}$ & $\begin{array}{l}\text { Major Model Changes } \\
\text { for Q1 } 2016\end{array}$ \\
\hline Residential & $\$ 0.17$ & $\$ 0.15$ & $\$ 0.02$ & $\begin{array}{l}\text { More inverter options } \\
\text { added }\end{array}$ \\
\hline Commercial & $\$ 0.08$ & $\$ 0.07$ & $\$ 0.01$ & (see Footnote 3) \\
\hline $\begin{array}{l}\text { Utility-Scale } \\
\text { (fixed-tilt) }\end{array}$ & $\$ 0.35$ & $\begin{array}{l}\$ 0.33 \\
=\$ 0.08 \text { (actual } \\
\text { cost decline } \\
\text { before model } \\
\text { change) } \\
+\$ 0.12 \text { (EPC } \\
\text { cost decline after } \\
\text { model change) } \\
+\$ 0.13 \\
\text { (developer cost } \\
\text { decline after } \\
\text { model change) }\end{array}$ & $\$ 0.02$ & $\begin{array}{l}\text { More aggressive } \\
\text { economies of scale } \\
\text { applied on EPC and } \\
\text { developer costs to reflect } \\
\text { labor productivity, } \\
\text { construction logistics, bulk } \\
\text { price, and discounted } \\
\text { developer overhead for } \\
\text { larger systems }\end{array}$ \\
\hline
\end{tabular}

In Q1 2016, the year-to-year nominal cost declines before model changes are $\$ 0.15 / \mathrm{Wdc}$ (residential), \$0.07/Wdc (commercial), and \$0.08/Wdc (utility-scale). Lower module and inverter prices contributed to these cost reductions. Increased competition, lower installer and developer overheads, improved labor productivity, and optimized system configurations also contributed, particularly for EPC firms building commercial and utility-scale projects.

As Figure ES-1 shows, hardware cost reductions (module and inverter prices, in particular) were an even more important driver of system cost reductions in earlier years, but the size of these gains has decreased recently. This has increased the importance of non-hardware, or "soft," costs. ${ }^{5}$ Figure ES- 2 shows the growing contribution from soft costs, particularly in the residential and commercial sectors. ${ }^{6}$ Soft costs and hardware costs also interact with each other. For instance, module efficiency improvements have reduced the number of modules required to construct a system of a given size, thus reducing hardware costs, and this trend has also reduced soft costs from direct labor and related installation overhead.

Finally, our results model "typical" systems across states and the entire country. When making more detailed comparisons, cost differences due to regional variations, system configurations

\footnotetext{
${ }^{5}$ Soft cost $=$ total cost - hardware (module, inverter, structural and electrical balance of system) cost.

${ }^{6}$ An increasing soft cost proportion in Figure ES-2 indicates soft costs declined more slowly than hardware costs; it does not indicate soft costs increased on an absolute basis.
} 
(such as with or without module-level power electronics, fixed-tilt vs. one-axis tracker, and small vs. large system size), and business structures (such as installer vs. integrator, and EPC vs. developer) should be considered. Different scenarios result in different costs, so consistent comparisons can only be made when cost scenarios are aligned.

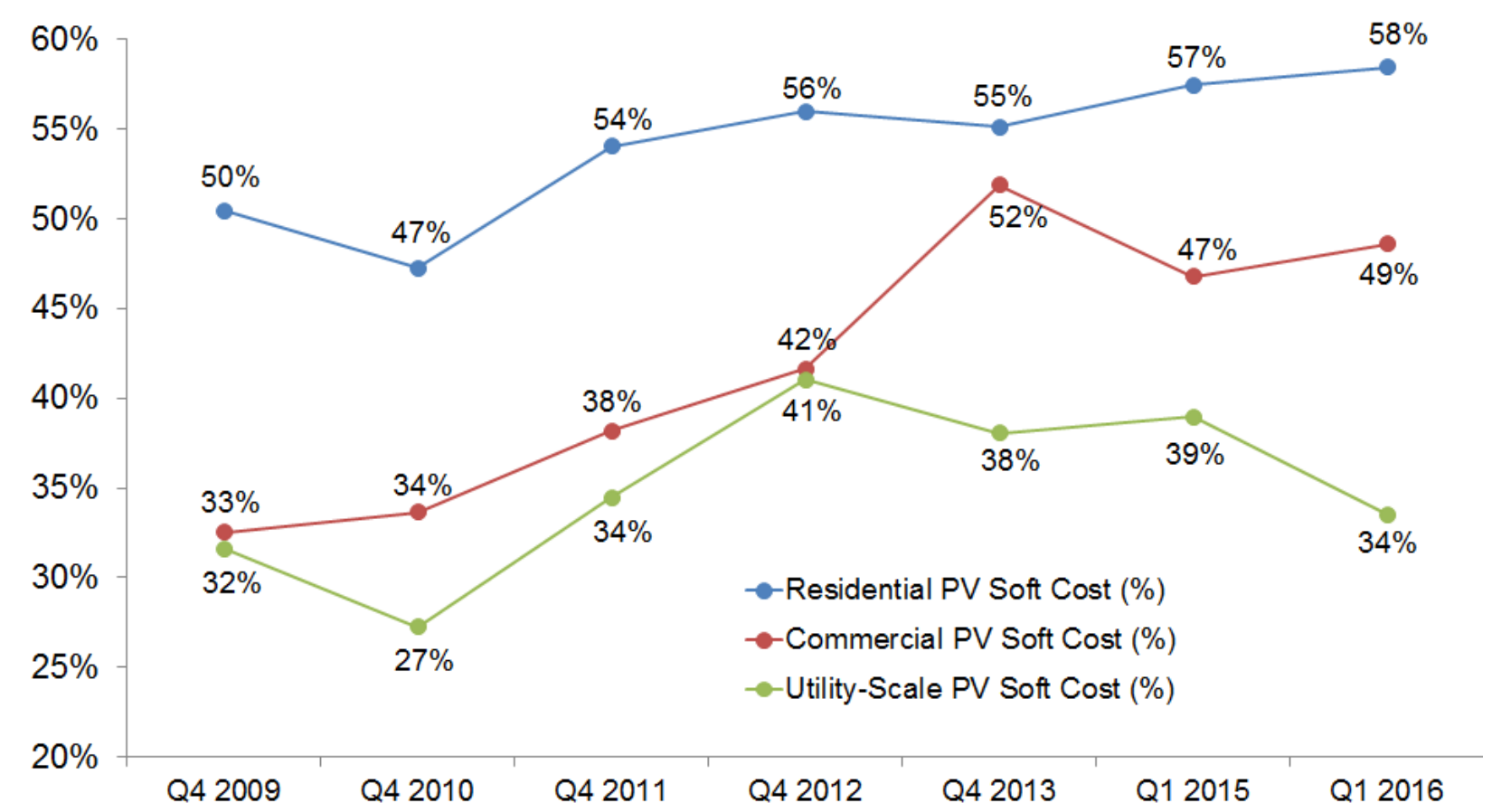

Figure ES-2. Modeled trend of soft cost as a proportion of total cost by sector, Q4 2009-Q1 2016 


\section{Table of Contents}

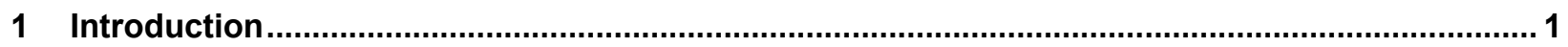

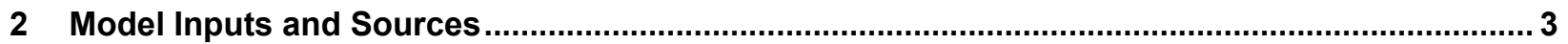

2.1 California's NEM Interconnection Applications Data Set.................................................. 3

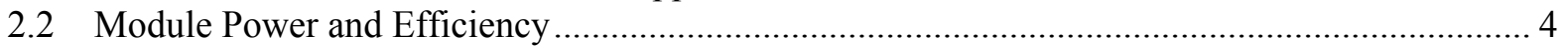

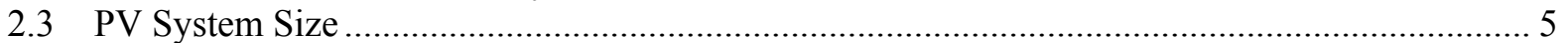

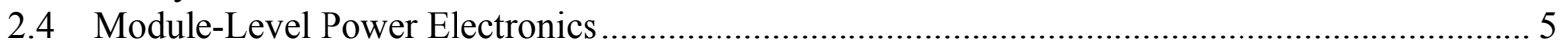

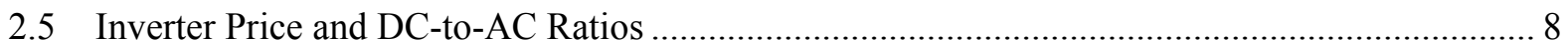

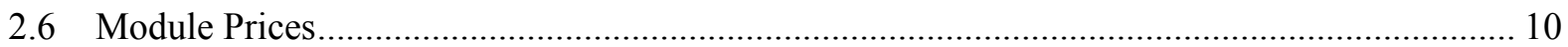

2.7 Installers vs. Integrators in the Residential PV Model ........................................................ 11

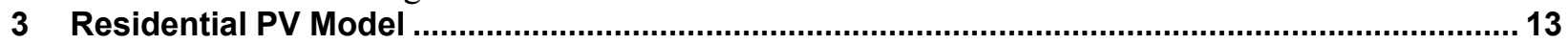

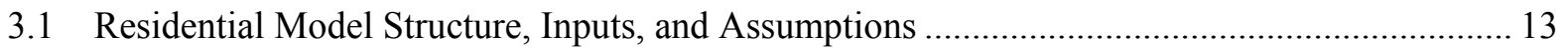

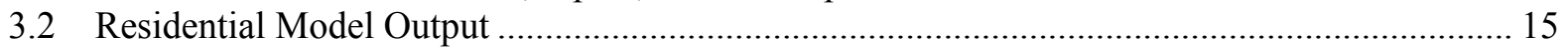

3.3 Residential Model Output vs. Reported Costs .......................................................................... 17

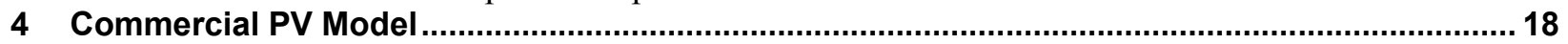

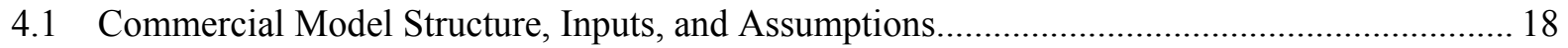

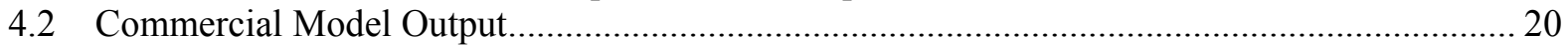

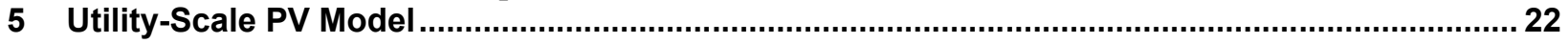

5.1 Utility-Scale Model Structure, Inputs, and Assumptions .................................................... 22

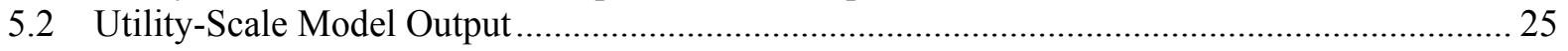

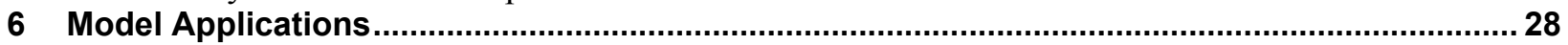

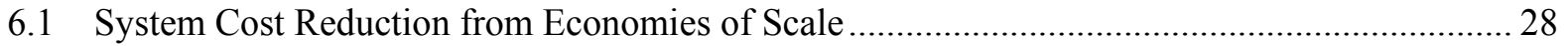

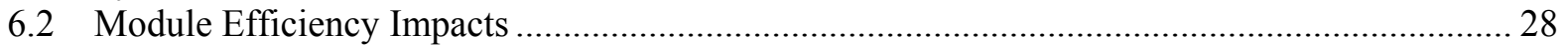

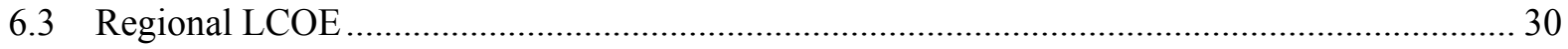

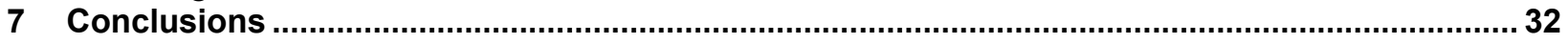

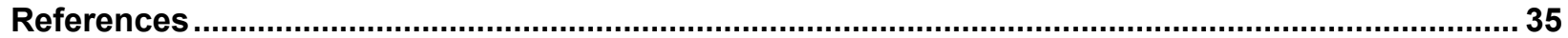




\section{List of Figures}

Figure ES-1. NREL PV system cost benchmark summary (inflation adjusted), Q4 2009-Q1 2016...v

Figure ES-2. Modeled trend of soft cost as a proportion of total cost by sector, Q4 2009Q1 2016 vii

Figure 1. U.S. PV market growth, 2004-2015, in gigawatts of direct current (DC) capacity (Bloomberg 2016)

Figure 2. Installed capacities of residential and commercial PV systems covered by the California NEM database (Go Solar CA 2016) compared with total installed capacities, 2010-2015.

Figure 3. Module power and efficiency trends from the California NEM database (Go Solar CA 2016), 2010-2015

Figure 4. PV system size trends from the California NEM database (Go Solar CA 2016), 2010-2015

Figure 5. Residential inverter market in California from the California NEM database (Go Solar

CA 2016), 2010-2015 ..........................................................................................

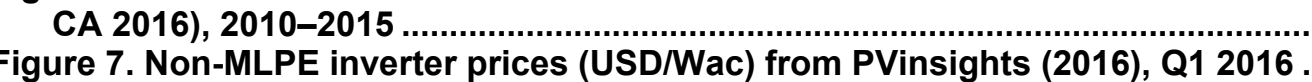

Figure 8. MLPE inverter shipments and prices (USD/Wac) from public corporate filings (Enphase 2016, SolarEdge 2016), Q1 2014-Q1 2016 ...

Figure 9. Adjusted ex-factory gate ASP for U.S. crystalline silicon modules from Bloomberg (2016) data, Q1 2016

ure 10. Residential PV market share: integrator vs. installer, Q1 2014-Q1 2016 (GTM

Researchand SEIA 2016, SolarCity 2016, Sunrun 2016, Vivint Solar 2016).

Figure 11. Residential PV: model structure.

Figure 12. Q1 2016 U.S. benchmark: 5.6-kW residential system cost (2016 USD/Wdc) .................. 16

Figure 13. Q1 2016 benchmark by location: 5.6-kW residential system cost (2016 USD/Wdc) ........ 16

Figure 14. Q1 2016 NREL modeled cost benchmark (2016 USD/Wdc) vs. Q4 2015 companyreported costs.

Figure 15. Commercial PV: model structure

Figure 16. Q1 2016 U.S. benchmark: commercial system cost (2016 USD/Wdc) ........................... 20

Figure 17. Q1 2016 benchmark by location: 200-kW commercial system cost (2016 USD/Wdc) ..... 21

Figure 18. Utility-scale PV: model structure.

Figure 19. Utility-scale PV: 2015 capacity installed and percentage of unionized labor by state

(BLS 2016, GTM Research and SEIA 2016).

Figure 20. Q1 2016 benchmark by location: 100-MW utility-scale PV systems, EPC only (2016 USD/Wdc)

Figure 21. Q1 2016 U.S. benchmark: utility-scale PV total cost (EPC + developer) 2016 USD/Wdc

Figure 22. Model application: U.S. utility-scale fixed-tilt PV system cost reduction from economies of scale (2016 USD/Wdc)

Figure 23. Modeled impacts of module efficiency on total system costs, 2016.

Figure 24. Modeled real LCOE $(\phi / \mathrm{kWh})$ for a 100-MWdc utility-scale PV system with fixed-tilt and one-axis tracking in 2016.

Figure 25. NREL PV system cost benchmark summary (inflation adjusted), Q4 2009-Q1 2016..... 33

Figure 26. Modeled trend of soft cost as a proportion of total cost by sector, Q4 2009-Q1 2016 ... 34 


\section{List of Tables}

Table ES-1. Benchmark and Model Change Summary iv

Table ES-2. Q1 2016 NREL PV System Cost Benchmark Change (USD per watt DC [Wdc]) .............. vi

Table 1. Comparison of Inverter Solutions: String Inverter, DC Power Optimizer, and Microinverter.

Table 2. Inverter Price Conversion (2016 USD). 6

Table 3. Residential PV: Modeling Inputs and Assumptions ....................................................... 14

Table 4. Commercial PV: Modeling Inputs and Assumptions .................................................... 19

Table 5. Utility-Scale PV: Modeling Inputs and Assumptions ........................................................ 23

Table 6. Q1 2016 NREL PV System Cost Benchmark Change (USD/Wdc)......................................... 34 


\section{Introduction}

Solar photovoltaic (PV) deployment has grown rapidly in the United States over the past several years. As Figure 1 shows, the compound annual growth rates for the U.S. residential, commercial, and utility-scale PV sectors from 2010-2015 were 46\%, 43\%, and 101\%, respectively. Utility-scale PV has been the solar industry's largest segment consistently since 2012 (Bloomberg 2016). At the same time, PV system costs have declined dramatically. Previous modeling by the National Renewable Energy Laboratory (NREL) shows system cost reductions of about 60\% across sectors between the fourth quarter of 2009 (Q4 2009) and Q1 2015.

\section{Gigawatt DC}

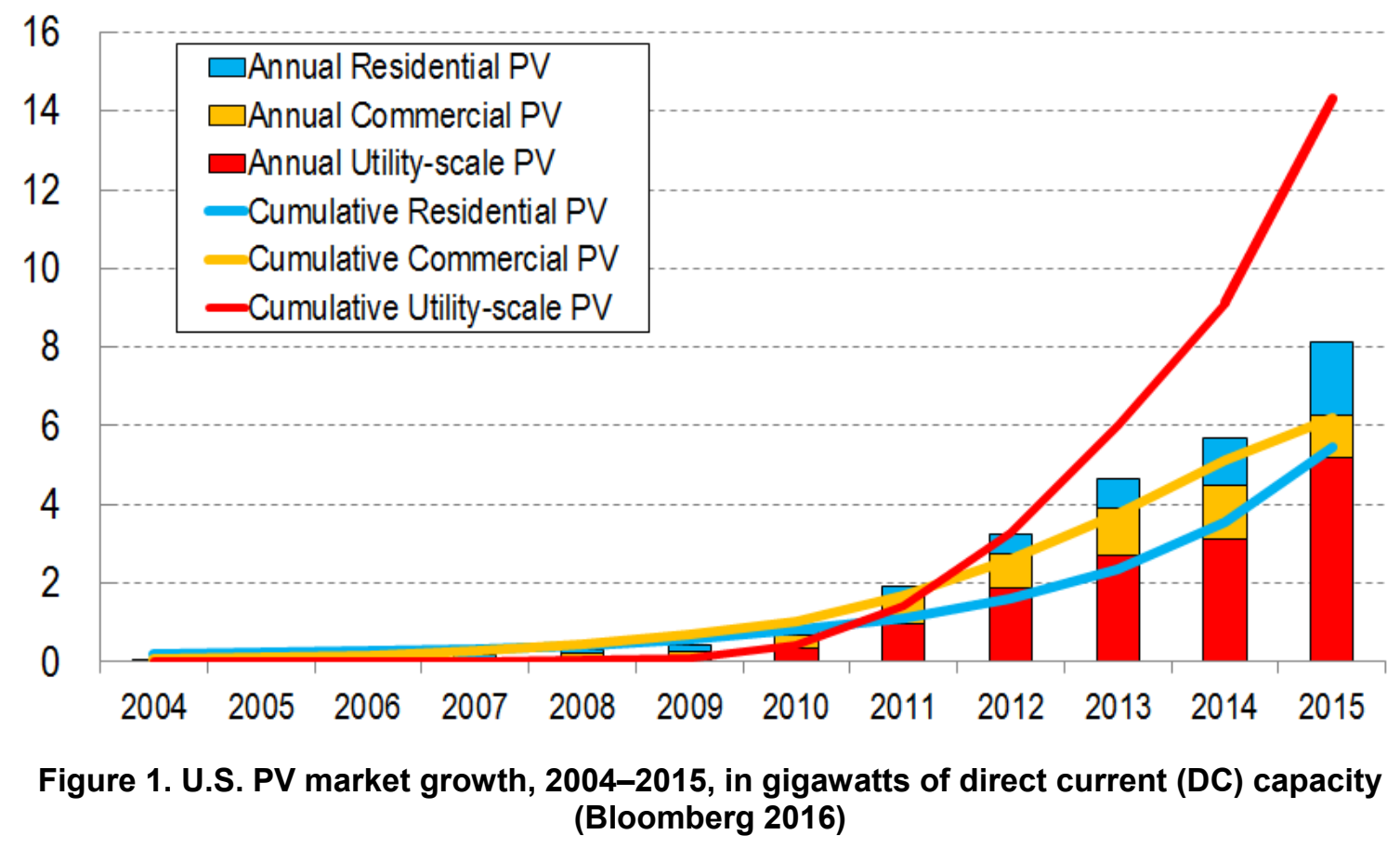

This report continues tracking cost reductions by benchmarking costs of U.S. PV for residential, commercial, and utility-scale systems built in Q1 2016. It is produced in conjunction with several related research activities at NREL and Lawrence Berkeley National Laboratory, which are documented in Ardani and Margolis (2015), Barbose and Darghouth (2015), Bolinger and Seel (2015), Chung et al. (2015), Feldman et al. (2015), and Fu et al. (2015a).

Our methodology includes bottom-up accounting for all system and project-development costs incurred when installing residential, commercial, and utility-scale systems, and it models the costs for such systems. In general, we attempt to model the typical installation techniques and business operations from an installed-cost perspective, and our benchmarks are national averages of installed capacities, weighted by state. The residential benchmark is further averaged across installer and integrator business models, weighted by market share. All benchmarks assume nonunion construction labor, although union labor cases are estimated for utility-scale systems.

Our modeled costs can be interpreted as the sales price an engineering, procurement, and construction (EPC) contractor/developer might charge for a system before any developer fee or 
price gross-up. We use this approach owing to the wide variation in developer profits in all three sectors, where project pricing is highly dependent on region and project specifics such as local retail electricity rate structures, local rebate and incentive structures, competitive environment, and overall project or deal structures.

The remainder of this report is organized as follows. Section 2 describes our model inputs and sources. Sections 3, 4, and 5 show specific model inputs and outputs for the residential, commercial, and utility-scale PV sectors. Section 6 includes three additional applications of our cost modeling: system cost reduction from economies of scale, module efficiency impacts, and regional levelized costs of energy (LCOEs). Section 7 puts the results in context with cost benchmarks over the past several years and offers conclusions. 


\section{Model Inputs and Sources}

This section describes our model inputs and sources. Section 2.1 describes our main data source, California's Net Energy Metering (NEM) Interconnection Applications Data Set. Sections 2.2 through 2.6 detail the inputs for the various components affecting PV system cost, and Section 2.7 describes how we allocated installations to installers versus integrators in the residential PV model.

\subsection{California's NEM Interconnection Applications Data Set}

Previous NREL analyses used the California Solar Initiative Data Set (CSI 2016), but, as that program has wound down, the number of new PV incentive applications (and consequently the data collection) has decreased substantially. As a result, for this analysis we use the robust California NEM Interconnection Applications Data Set instead (Go Solar CA 2016). This database is updated monthly and contains all interconnection applications in the service territories of the state's three investor-owned utilities (Pacific Gas \& Electric, Southern California Edison, and San Diego Gas \& Electric). Collectively 47\% of the PV in the United States is integrated into these three utilities (SEPA 2016). We use the database to benchmark generic system characteristics, such as system size, module power and efficiency, and choice of power electronics. Although there are other databases for other markets, such as Massachusetts and New York, we use only the California NEM database because of its higher granularity and consistency. However, we do not use the California NEM database for regional cost analyses; inputs and sources for regional analyses are described in subsequent sections of this report.

As shown in Figure 2, the California NEM database captures most residential capacity in California (89\% of installed capacity in 2014 and $73 \%$ in 2015) and a sizable portion of commercial capacity (55\% of installed capacity in 2014 and $27 \%$ in 2015). Note that:

- We analyze only rooftop systems in the database for the residential and commercial sectors. We exclude ground-mounted systems.

- We exclude systems with only alternating current (AC) power records.

- We exclude systems that were still in the validation phase. 


\section{Annual Installation (MW DC)}

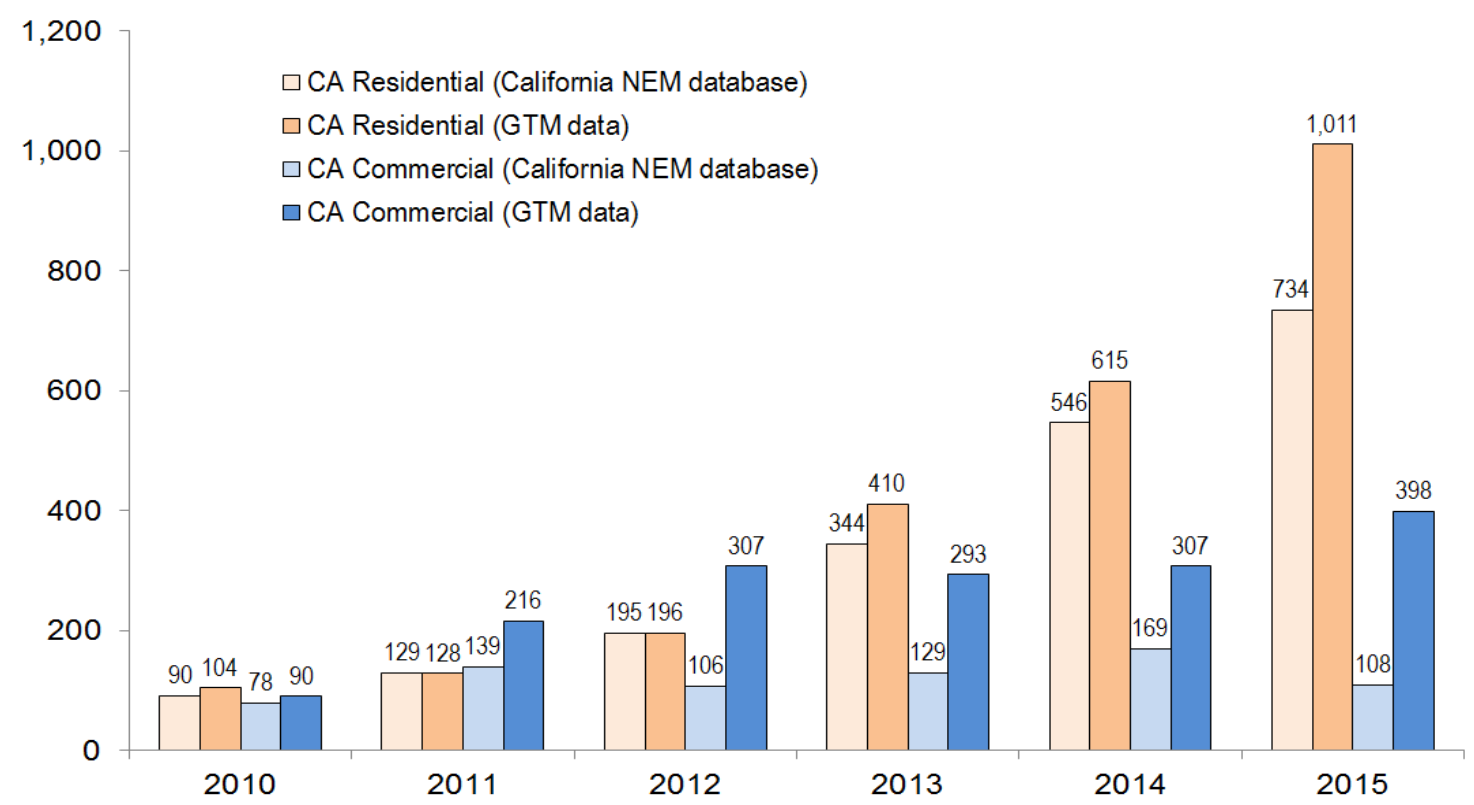

Figure 2. Installed capacities of residential and commercial PV systems covered by the California NEM database (Go Solar CA 2016) compared with total installed capacities, 2010-2015

\subsection{Module Power and Efficiency}

Figure 3 displays module power and efficiency data from the California NEM database. Since 2010, module power and efficiency have been consistently higher in the commercial sector than in the residential sector, although both sectors have been steadily improving. We use the values of $15.6 \%$ (residential) and $16.7 \%$ (commercial and utility-scale) module efficiency.

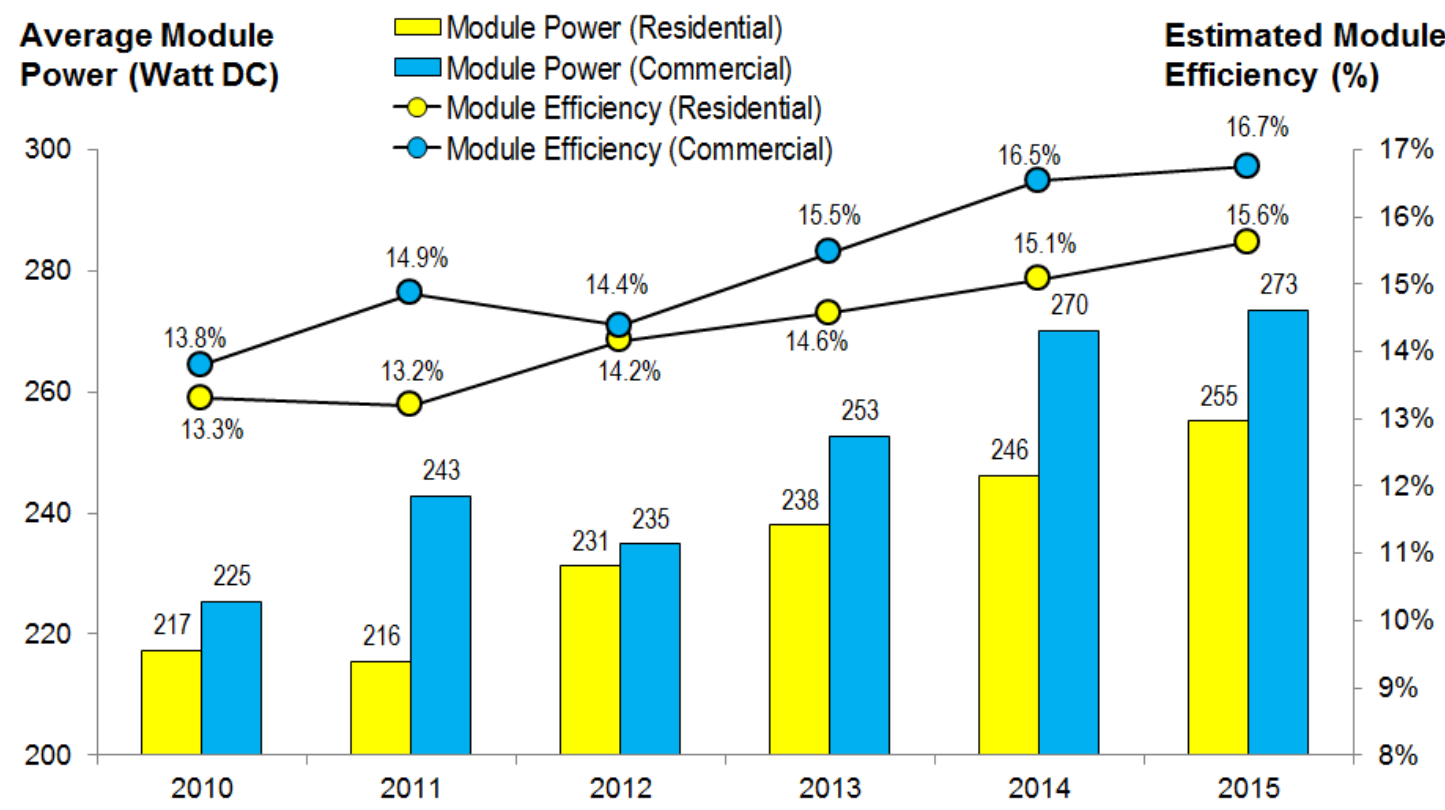

Figure 3. Module power and efficiency trends from the California NEM database (Go Solar CA 2016), 2010-2015 


\subsection{PV System Size}

Figure 4 displays average system sizes from the California NEM database. Average residential system sizes have not changed significantly over the past 5 years. We use the 2015 value of 5.6 kilowatts $(\mathrm{kW})$ as the baseline case in our cost model. Conversely, commercial system sizes have changed more frequently, likely reflecting the wide scope for "commercial customers," which include schools, office buildings, malls, retail stores, and government projects. We use $200 \mathrm{~kW}$ as the baseline case in our model.

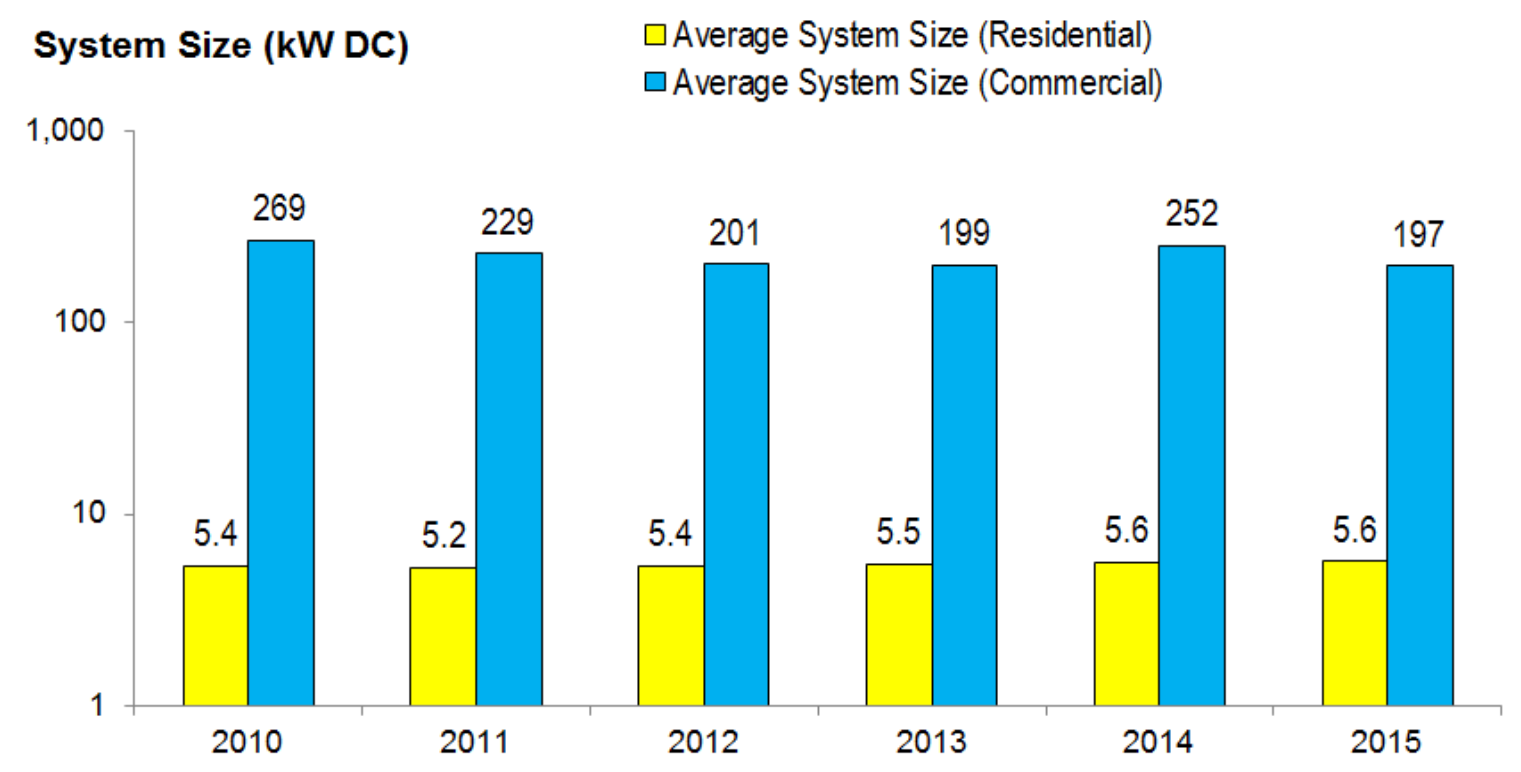

Figure 4. PV system size trends from the California NEM database (Go Solar CA 2016), 2010-2015

\subsection{Module-Level Power Electronics}

Microinverters and DC power optimizers are collectively referred to as module-level power electronics (MLPE). By allowing designs with different roof configurations (orientations and tilts) and constantly tracking the maximum power point for each module, MLPE provide an optimized design solution at the module level. Today, Enphase (microinverters) and SolarEdge (DC power optimizers) are the leading companies offering MLPE solutions. Table 1 provides a brief comparison between traditional string inverters and MLPE. 
Table 1. Comparison of Inverter Solutions: String Inverter, DC Power Optimizer, and Microinverter

\begin{tabular}{|c|c|c|c|}
\hline & String Inverter & DC Power Optimizer & Microinverter \\
\hline Function & $\begin{array}{l}\text { PV modules are } \\
\text { connected in parallel by } \\
\text { one or multiple strings } \\
\text { and then directly } \\
\text { connected to the string } \\
\text { inverter for DC-to-AC } \\
\text { conversion. If one } \\
\text { module is shaded, the } \\
\text { whole string is impacted. }\end{array}$ & $\begin{array}{l}\text { Each PV module has one } \\
\text { power optimizer for DC-to- } \\
\text { DC conversion, so the } \\
\text { traditional junction box is } \\
\text { replaced, and all modules } \\
\text { are connected by string } \\
\text { inverter for DC-to-AC } \\
\text { conversion. Shading only } \\
\text { impacts individual } \\
\text { modules. }\end{array}$ & $\begin{array}{l}\text { Each PV module has one } \\
\text { microinverter for DC-to- } \\
\text { AC conversion, and thus } \\
\text { no string inverter is used. } \\
\text { Shading only impacts } \\
\text { individual modules. }\end{array}$ \\
\hline $\begin{array}{l}\text { Relative } \\
\text { product price }\end{array}$ & Low & Medium & High \\
\hline $\begin{array}{l}\text { Performance in } \\
\text { shading }\end{array}$ & Poor & More efficient & More efficient \\
\hline $\begin{array}{l}\text { Performance in } \\
\text { various } \\
\text { directions or on } \\
\text { irregular roofs }\end{array}$ & Low & Medium & High \\
\hline $\begin{array}{l}\text { Module-level } \\
\text { monitoring and } \\
\text { troubleshooting }\end{array}$ & No & $\begin{array}{l}\text { Yes (e.g., SolarEdge } \\
\text { Cellular Kit) }\end{array}$ & $\begin{array}{l}\text { Yes (e.g., Enphase } \\
\text { "Envoy + Enlighten") }\end{array}$ \\
\hline $\begin{array}{l}\text { Improved } \\
\text { energy yield } \\
\text { from module } \\
\text { mismatch } \\
\text { reduction }\end{array}$ & No & Yes & Yes \\
\hline $\begin{array}{l}\text { Number of } \\
\text { electronic } \\
\text { components }\end{array}$ & Normal & $\begin{array}{l}\text { Greater (thus may have } \\
\text { some component risks) }\end{array}$ & $\begin{array}{l}\text { Greater (thus may have } \\
\text { some component risks) }\end{array}$ \\
\hline $\begin{array}{l}\text { Safety for } \\
\text { installation }\end{array}$ & Normal & Safer; easier wiring work & $\begin{array}{l}\text { Safest; use only AC cable } \\
\text { with no high-voltage DC } \\
\text { power. }\end{array}$ \\
\hline
\end{tabular}

According to the California NEM database, market uptake of MLPE has been growing rapidly since 2010 in California's residential sector (Figure 5). This increasing market growth may be driven by the decreasing MLPE costs and by the "rapid shutdown" on buildings required by Article 690.12 of the National Electric Code since 2014-MLPE inherently meet rapid-shutdown requirements without the need to install additional electrical equipment.

In 2015, the combined Enphase and SolarEdge inverter solutions reached $46 \%$ of the total California residential market share (Figure 5). Therefore, we update our residential system cost model with new functions to estimate the costs of these MLPE inverter solutions. Conversely, MLPE growth has been slow in California's commercial sector, reaching a share of only $11 \%$ in 2015 (Figure 6). Thus, we do not build MLPE inverter solutions into our commercial model. 
Annual Installation (MW DC)

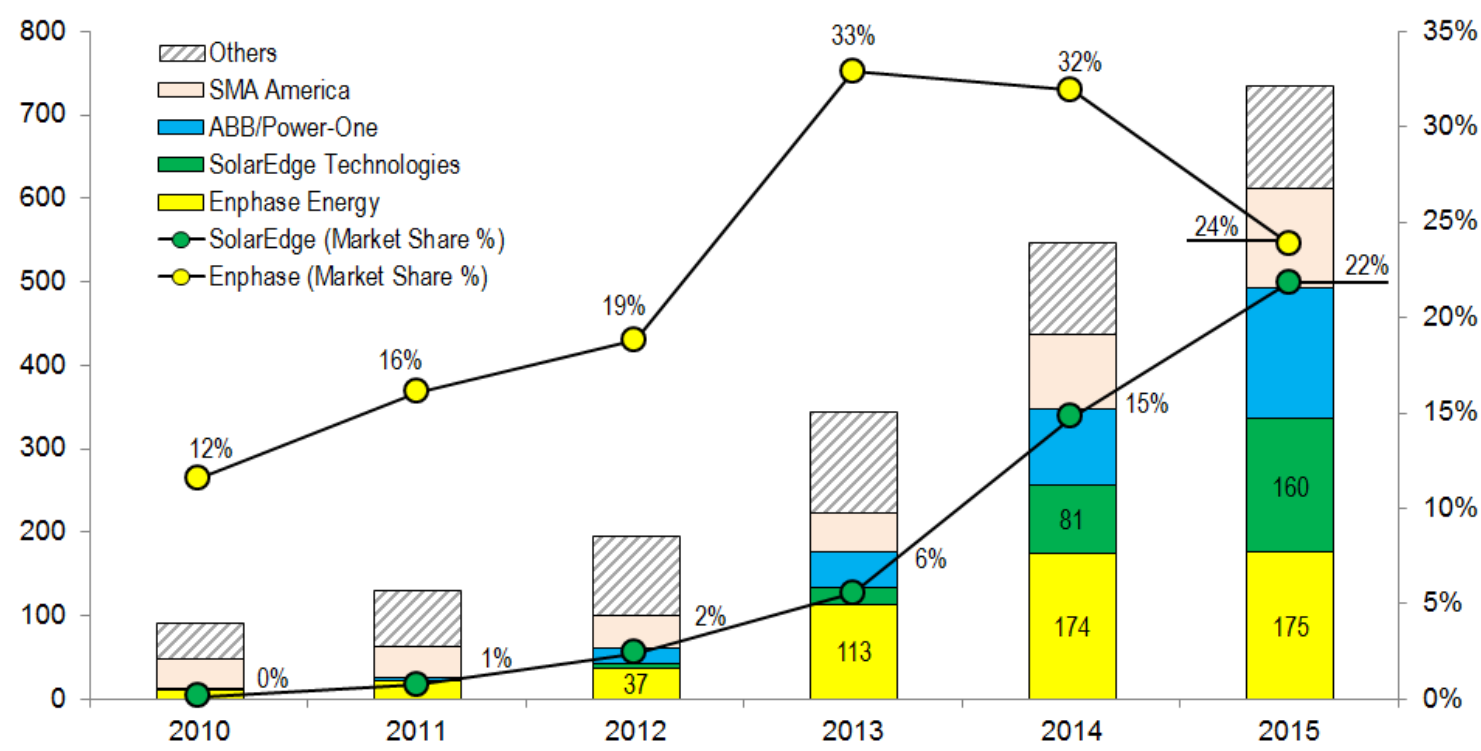

Figure 5. Residential inverter market in California from the California NEM database (Go Solar CA 2016), 2010-2015

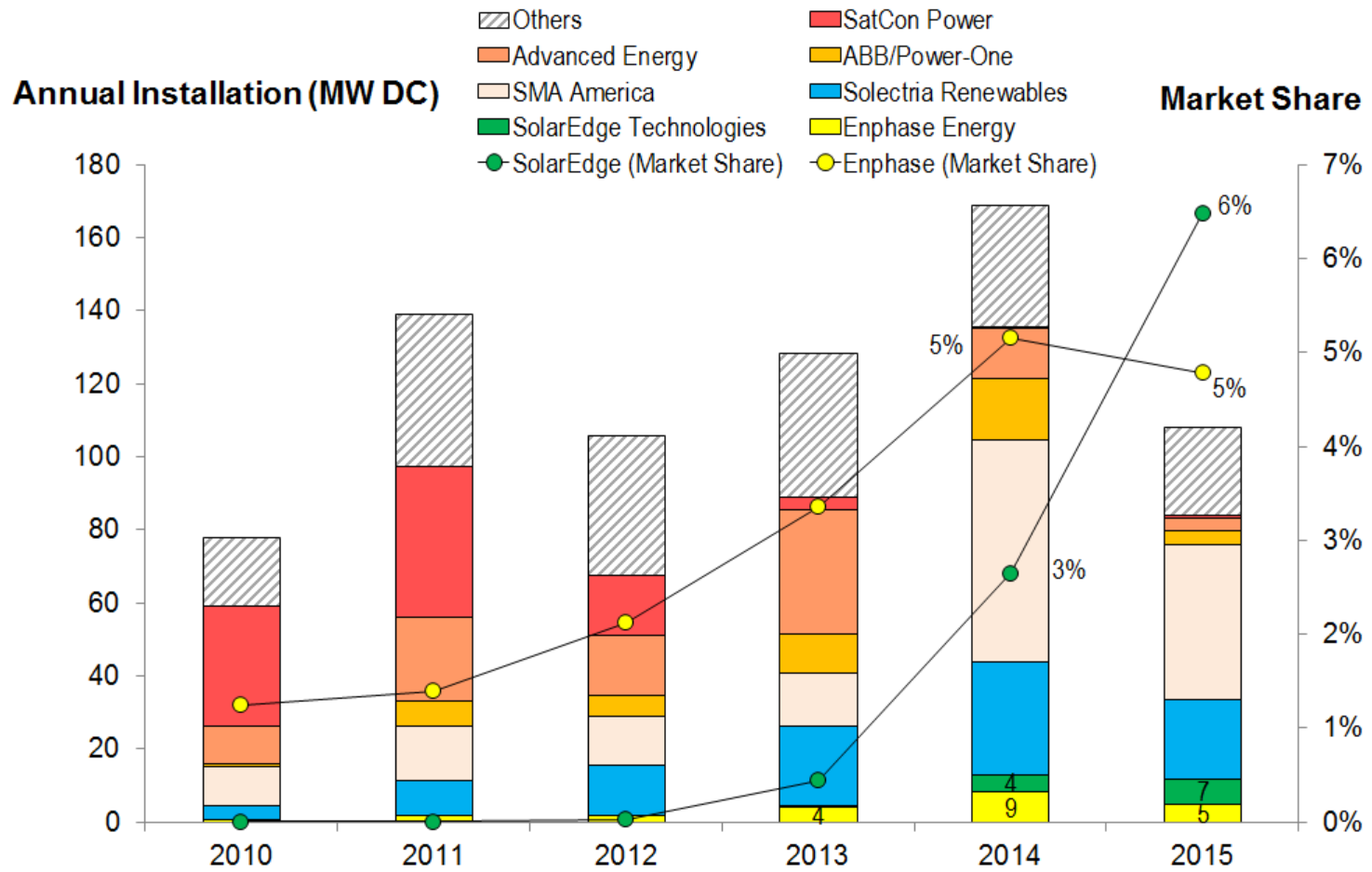

Figure 6. Commercial inverter market in California from the California NEM database (Go Solar CA 2016), 2010-2015

7 "Others" represents other companies with small market shares. Although some companies may also have MLPEbased inverter products, we assume that SolarEdge and Enphase are the representatives of MLPE inverter manufacturers. 


\subsection{Inverter Price and DC-to-AC Ratios}

As shown in Figure 7, we source non-MLPE inverter prices - in U.S. dollars (USD) per watt AC (Wac) - from the PVinsights (2016) database, which contains typical prices between Tier 1 suppliers and developers in the market. For MLPE inverter prices, we use data from public corporate filings, shown in Figure 8 (Enphase 2016; SolarEdge 2016). Q1 2016 Enphase revenue was $\$ 0.45 / \mathrm{Wac}$, which represents the typical microinverter price. Q1 2016 SolarEdge revenue was $\$ 0.30 / \mathrm{Wac}$, including sales from DC power optimizers, string inverters, and monitoring equipment, typically included in one product offering. GTM Research estimates that the DC power optimizer cost $\$ 0.10 /$ Wac (GTM Research 2015), implying a string inverter and monitoring equipment price of $\$ 0.20 / \mathrm{Wac}$, which is consistent with average residential string inverter costs of \$0.18/Wac in Q1 2016 (assuming a \$0.02-0.03/Wac cost for monitoring equipment) (GTM Research and SEIA 2016).

We then convert the USD/Wac inverter prices from Figure 7 and Figure 8 to USD per watt DC (Wdc) using the different DC-to-AC ratios (Table 2). In our benchmark, we use USD/Wdc for all costs including inverter prices.

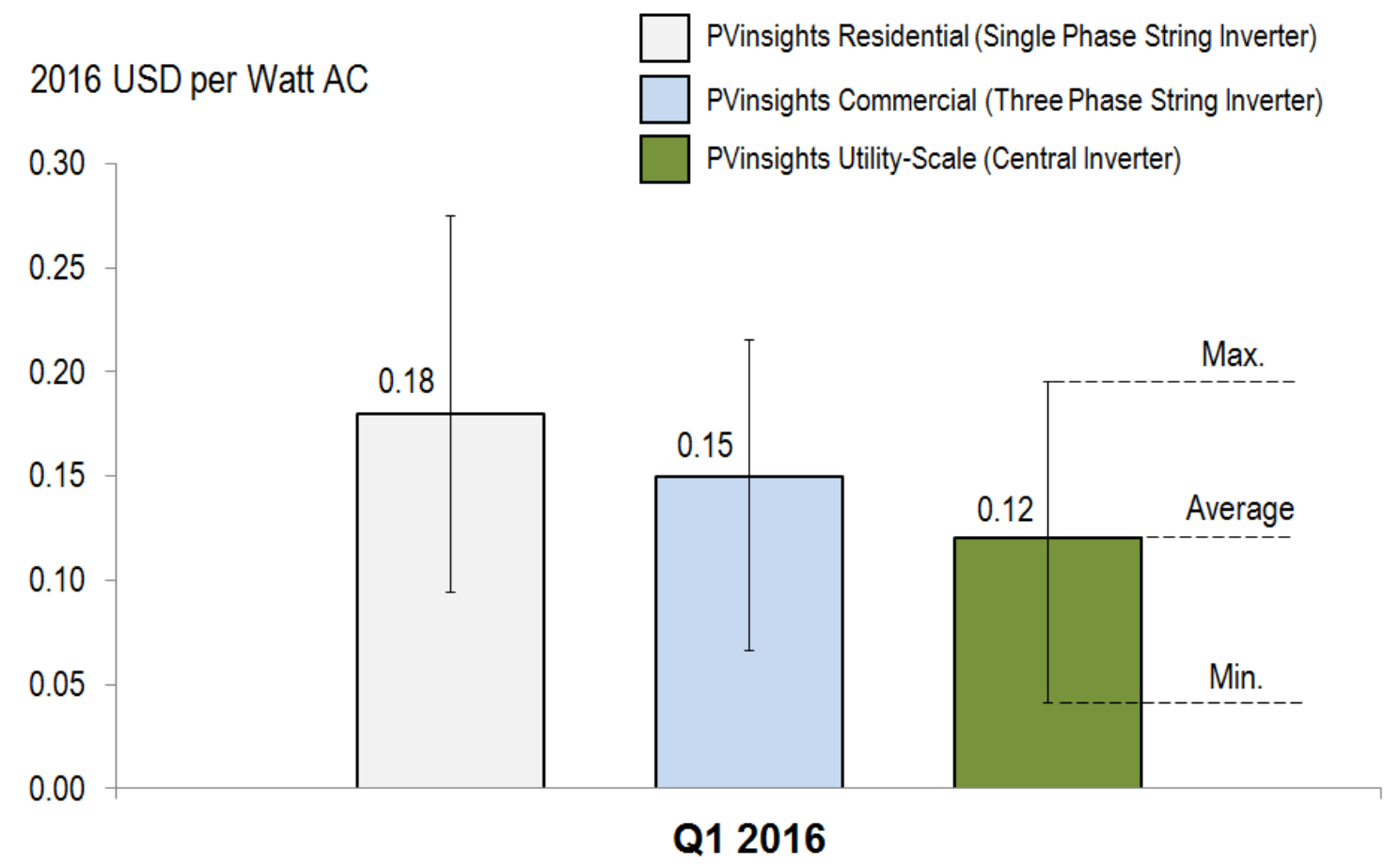

Figure 7. Non-MLPE inverter prices (USD/Wac) from PVinsights (2016), Q1 2016 


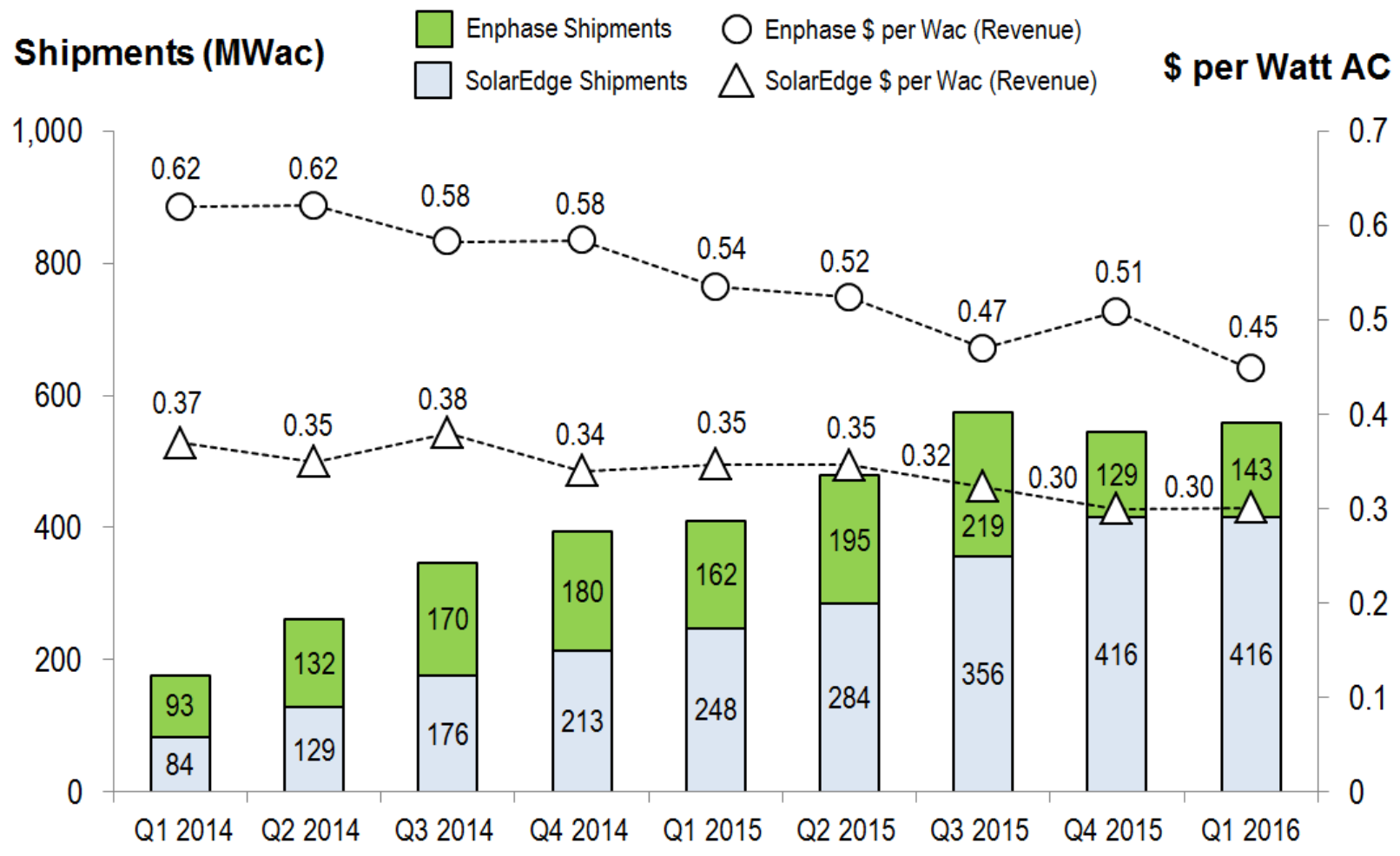

Figure 8. MLPE inverter shipments and prices (USD/Wac) from public corporate filings (Enphase 2016; SolarEdge 2016), Q1 2014-Q1 2016

Table 2. Inverter Price Conversion (2016 USD)

\begin{tabular}{lllll}
\hline Inverter Type & Sector & USD/Wac & DC-to-AC Ratio & USD/Wdc \\
\hline $\begin{array}{l}\text { Single-Phase String } \\
\text { Inverter }\end{array}$ & $\begin{array}{l}\text { Residential PV (non- } \\
\text { MLPE) }\end{array}$ & 0.176 & 1.15 & 0.15 \\
\hline $\begin{array}{l}\text { Microinverter } \\
\text { Residential PV } \\
\text { (MLPE) }\end{array}$ & 0.45 & 1.15 & 0.39 \\
$\begin{array}{l}\text { DC Power Optimizer } \\
\text { String Inverter }\end{array}$ & $\begin{array}{l}\text { Residential PV } \\
\text { (MLPE) }\end{array}$ & 0.20 & 1.15 & 0.17 \\
\hline $\begin{array}{l}\text { Three-Phase String } \\
\text { Inverter }\end{array}$ & $\begin{array}{l}\text { Commercial PV (non- } \\
\text { MLPE) }\end{array}$ & 0.15 & 1.15 & 0.13 \\
\hline Central Inverter & $\begin{array}{l}\text { Utility-Scale PV (fixed- } \\
\text { tilt) }\end{array}$ & 0.12 & 1.40 (oversized) & 0.09 \\
\hline Central Inverter & $\begin{array}{l}\text { Utility-scale PV (1- } \\
\text { axis tracker) }\end{array}$ & 0.12 & 1.20 & 0.10 \\
\hline
\end{tabular}

\footnotetext{
${ }^{8}$ Fu et al. (2015a), NREL (2016).
} 


\subsection{Module Prices}

To estimate module prices, we use Bloomberg (2016) data to represent the typical average selling price (ASP) between Tier 1 module suppliers and first buyers in the global market (see Section 2.6.1 for a discussion on "first buyers"). Also, a 2016 Solar PV Market Research survey indicates a U.S. ASP discount of about $6 \%$ compared to the global market because of the country's large demand and competitive market condition (Mints 2016). Using this regional discount, we adjust the Bloomberg (2016) global module price data in Figure 9 and benchmark the Q1 2016 average U.S. crystalline silicon module ASP at \$0.64/W for all three sectors. While $\$ 0.64 / \mathrm{W}$ is lower than the global average, it is considerably higher than the average price in many markets, such as Europe and China, most likely owing to U.S. tariffs on Chinesemanufactured PV equipment.

Interviews conducted for this analysis suggest even lower prices $(\$ 0.58-0.60 / \mathrm{W})$ due to the recent liquidity issues of some large developers (NREL 2016). However, because this report only covers Q1 2016, we do not include the impact from company bankruptcy in April 2016.

Compared with module prices in 2015, module prices in 2016 have also been influenced by changes in currency exchange rates. The USD appreciated against the Chinese Yuan by $5 \%$ between Q1 2015 and Q1 2016 (XE Currency Charts 2016).

\section{USD per Watt DC}

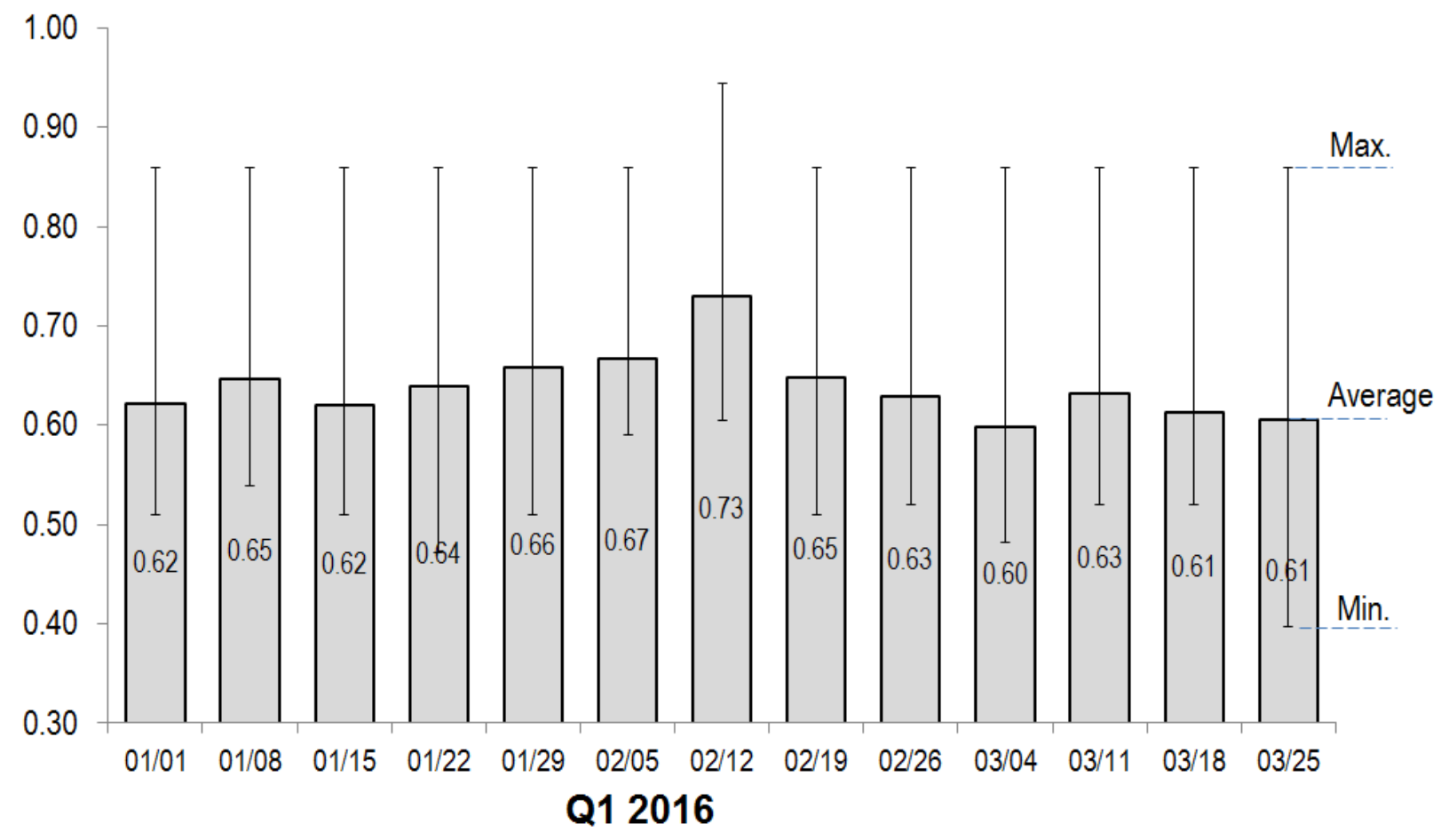

Figure 9. Adjusted ex-factory gate ASP for U.S. crystalline silicon modules from Bloomberg (2016) data, Q1 2016 


\section{"First Buyer ASP"}

The first buyers of modules ex-factory gate can be developers, EPC contractors, installers, distributors, retailers, or other end users. In our cost model, first buyer ASP is used as the "module price" component of the total system cost. Two other price concepts are used in the literature (Mints 2016) but not used as the "module price" in our model:

- Resale Module Price from Distributors and Retailers: Both distributors and retailers can buy modules in bulk quantity and receive a discount. In a resale and secondary market, distributors and retailers can resell modules to smaller end users, such as local installers. This resale price tends to be higher than first buyer ASP is.

- Inventory Module Price from End Users: Prior to the construction phase, developers and installers usually hold large module quantity in their inventory for a long time to match their estimated pipeline. If the project is discontinued or the pipeline is overestimated, modules in inventory will be sold at a deep discount. This inventory price tends to be lower than first buyer ASP is.

Historically in the PV industry, module ASP is not solely correlated with module manufacturing cost. Although manufacturing cost is an important factor for ASP (Fu et al. 2015b), other factors can sometimes be even more impactful. These include:

- Market conditions, such as supply and demand during a certain period

- Company strategies, such as aggressive pricing to win market share

- Government policies, such as incentives and tariffs

- End-user preferences, such as module quality and performance for PV system economics.

In short, first buyer ASP differs by region and by time. The use of first buyer ASP for "module price" in our model accounts for the four factors listed above.

\subsection{Installers vs. Integrators in the Residential PV Model}

Our residential PV benchmark is based on two different business structures: "installer" and "integrator." We define installers as businesses that engage in lead generation, sales, and installation but do not provide financing solutions. The integrator performs all of the installer's functions but does provide financing and system monitoring for third-party-owned systems. In our models, the difference between installers and integrators manifests in the overhead cost category, where the integrator is modeled with higher expenses for customer acquisition, financial structuring, and asset management.

To estimate the split in market share between installers and integrators, we use data compiled from corporate filings (SolarCity 2016; Sunrun 2016; Vivint Solar 2016) and GTM Research and SEIA (2016). As shown in Figure 10, a few integrators have accounted for more than $50 \%$ of the residential market since 2014 . We use the 50\% integrator and 50\% installer market shares evident in Q1 2016 to compute the national weighted-average case in our residential PV model. 


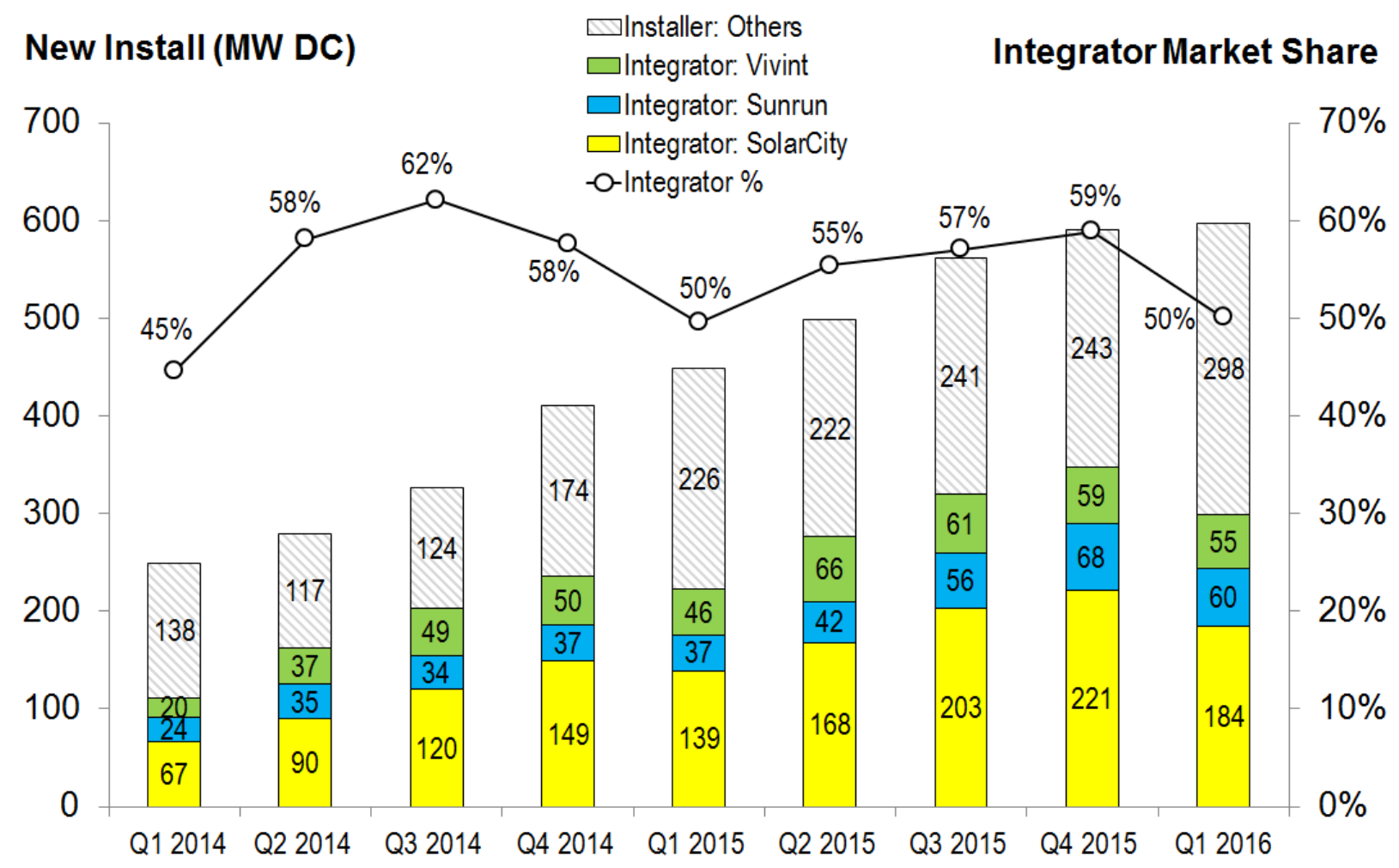

Figure 10. Residential PV market share: integrator vs. installer, Q1 2014-Q1 2016 (GTM Research and SEIA 2016; SolarCity 2016; Sunrun 2016; Vivint Solar 2016) 


\section{Residential PV Model}

This section describes our residential model's structure, inputs, and assumptions (Section 3.1), output (3.2), and differences between modeled output and reported costs (3.3).

\subsection{Residential Model Structure, Inputs, and Assumptions}

We model a 5.6-kW residential rooftop system using 60-cell, multicrystalline, 15.6\%-efficient modules from a Tier 1 supplier and a standard flush mount, pitched-roof racking system. Figure 11 presents the cost drivers and assumptions, cost categories, and inputs and outputs of the model. Table 3 presents modeling inputs and assumptions in detail.

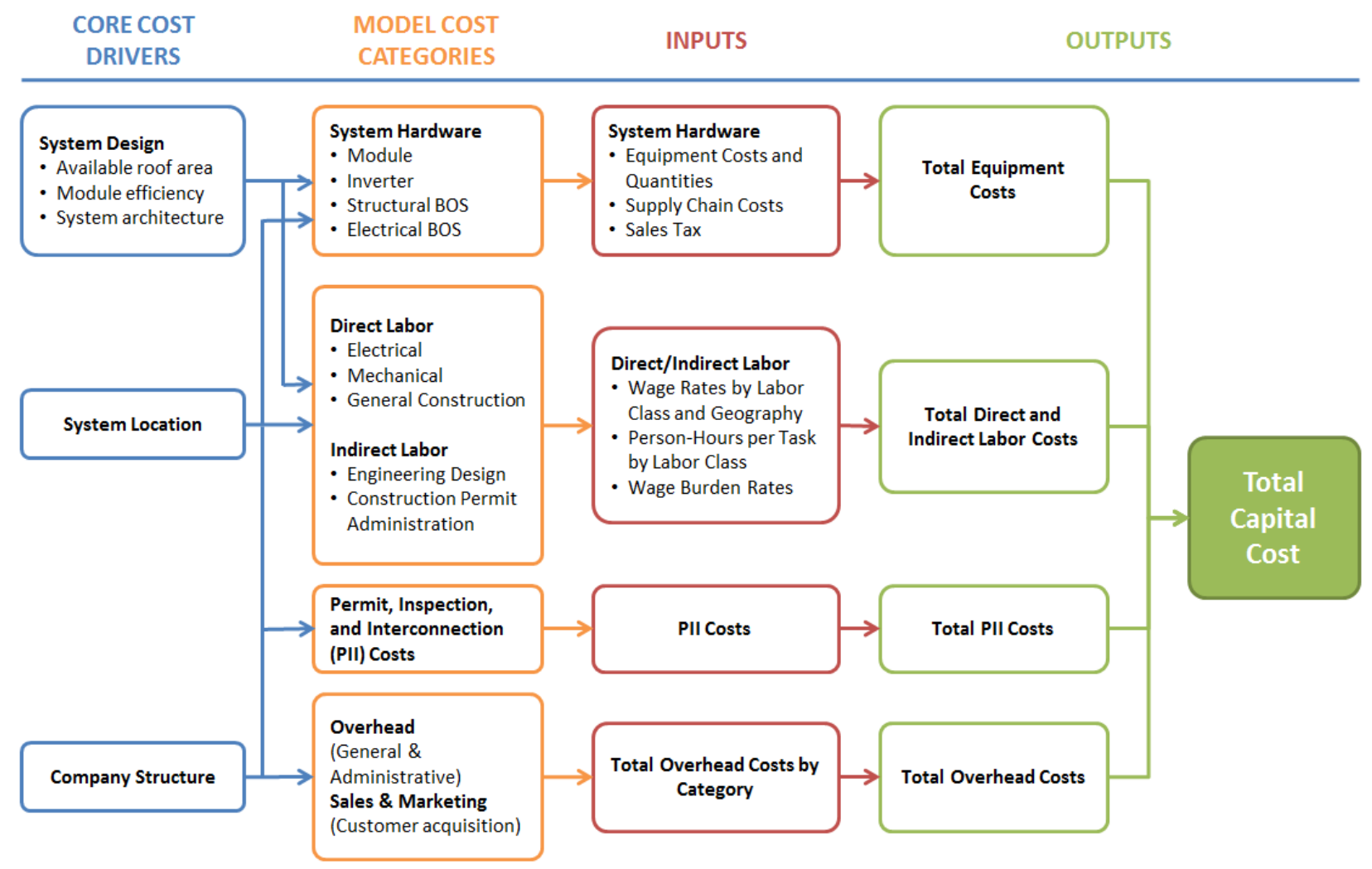

Figure 11. Residential PV: model structure 
Table 3. Residential PV: Modeling Inputs and Assumptions

\begin{tabular}{|c|c|c|c|}
\hline Category & Modeled Value & Description & Sources \\
\hline System size & $5.6 \mathrm{~kW}$ & Average installed size per system & Go Solar CA (2016) \\
\hline $\begin{array}{l}\text { Module } \\
\text { efficiency }\end{array}$ & $15.6 \%$ & Average module efficiency & Go Solar CA (2016) \\
\hline Module price & $\$ 0.64 / \mathrm{Wdc}$ & $\begin{array}{l}\text { Ex-factory gate (first buyer) ASP, Tier } 1 \\
\text { modules }\end{array}$ & $\begin{array}{l}\text { Bloomberg (2016), Mints } \\
\text { (2016), NREL (2016) }\end{array}$ \\
\hline Inverter price & $\begin{array}{l}\text { Single-phase } \\
\text { string inverter: } \\
\$ 0.15 / \mathrm{Wdc} \\
\text { DC power } \\
\text { optimizer string } \\
\text { inverter: } \\
\text { \$0.17/Wdc } \\
\text { Microinverter: } \\
\text { \$0.39/Wdc }\end{array}$ & $\begin{array}{l}\text { Ex-factory gate prices (first buyer) ASP, } \\
\text { Tier } 1 \text { inverters }\end{array}$ & $\begin{array}{l}\text { Go Solar CA (2016), NREL } \\
\text { (2016), PVinsights (2016), } \\
\text { corporate filings (Enphase } \\
\text { 2016; SolarEdge 2016) }\end{array}$ \\
\hline $\begin{array}{l}\text { Structural } \\
\text { balance of } \\
\text { system (BOS, } \\
\text { racking) }\end{array}$ & $\$ 0.12 / \mathrm{Wdc}$ & $\begin{array}{l}\text { Ex-factory gate prices; includes flashing for } \\
\text { roof penetrations }\end{array}$ & $\begin{array}{l}\text { Model assumptions, NREL } \\
\text { (2016) }\end{array}$ \\
\hline Electrical BOS & $\begin{array}{l}\$ 0.19- \\
\$ 0.35 / \mathrm{Wdc} \\
\text { Varies by } \\
\text { inverter option }\end{array}$ & $\begin{array}{l}\text { Wholesale prices for conductors, switches, } \\
\text { combiners and transition boxes, as well as } \\
\text { conduit, grounding equipment, monitoring } \\
\text { system or production meters, fuses, and } \\
\text { breakers }\end{array}$ & $\begin{array}{l}\text { Model assumptions, NREL } \\
\text { (2016), RSMeans (2015) }\end{array}$ \\
\hline $\begin{array}{l}\text { Supply chain } \\
\text { costs }(\% \text { of } \\
\text { equipment } \\
\text { costs) }\end{array}$ & $15.2 \%$ & $\begin{array}{l}15 \% \text { costs and fees associated with } \\
\text { inventory, shipping, and handing of } \\
\text { equipment multiplied by the cost of doing } \\
\text { business index }(101 \%)\end{array}$ & NREL (2016) \\
\hline Sales tax & $\begin{array}{l}\text { Varies by } \\
\text { location }\end{array}$ & $\begin{array}{l}\text { Sales tax on the equipment; national } \\
\text { benchmark applies an average (by state) } \\
\text { weighted by } 2015 \text { installed capacities }\end{array}$ & $\begin{array}{l}\text { DSIRE (2016), RSMeans } \\
(2015)\end{array}$ \\
\hline $\begin{array}{l}\text { Direct } \\
\text { installation } \\
\text { labor }\end{array}$ & $\begin{array}{l}\text { Electrician: } \\
\$ 19.01-\$ 37.52 \\
\text { per hour; } \\
\text { Laborer: } \\
\$ 12.41-\$ 24.63 \\
\text { per hour; } \\
\text { Varies by } \\
\text { location and } \\
\text { inverter option }\end{array}$ & $\begin{array}{l}\text { Modeled labor rate depends on state; } \\
\text { national benchmark uses weighted } \\
\text { average of state rates }\end{array}$ & BLS (2016), NREL (2016) \\
\hline $\begin{array}{l}\text { Burden rates } \\
\text { (\% of direct } \\
\text { labor) }\end{array}$ & $\begin{array}{l}\text { Total } \\
\text { nationwide } \\
\text { average: } 31.8 \%\end{array}$ & $\begin{array}{l}\text { Workers' compensation (state-weighted } \\
\text { average), federal and state unemployment } \\
\text { insurance, Federal Insurance Contributions } \\
\text { Act (FICA), builders risk, public liability }\end{array}$ & RSMeans (2015) \\
\hline
\end{tabular}




\begin{tabular}{|c|c|c|c|}
\hline Category & Modeled Value & Description & Sources \\
\hline PII & $\$ 0.10 / \mathrm{Wdc}$ & $\begin{array}{l}\text { Includes assumed building permitting fee of } \\
\$ 400 \text { and } 6 \text { office staff hours for building } \\
\text { permit preparation and submission, and } \\
\text { interconnection application preparation and } \\
\text { submission }\end{array}$ & $\begin{array}{l}\text { NREL (2016), Vote Solar } \\
\text { (2015), Vote Solar and } \\
\text { IREC (2013) }\end{array}$ \\
\hline $\begin{array}{l}\text { Sales \& } \\
\text { marketing } \\
\text { (customer } \\
\text { acquisition) }\end{array}$ & $\begin{array}{l}\$ 0.31 / \mathrm{Wdc} \\
\text { (installer) } \\
\$ 0.43 / \mathrm{Wdc} \\
\text { (integrator) }\end{array}$ & $\begin{array}{l}\text { Total cost of sales and marketing activities } \\
\text { over the last year-including marketing and } \\
\text { advertising, sales calls, site visits, bid } \\
\text { preparation, and contract negotiation; } \\
\text { adjusted based on state "cost of doing } \\
\text { business" index }\end{array}$ & Feldman et al. (2013) \\
\hline $\begin{array}{l}\text { Overhead } \\
\text { (general \& } \\
\text { administrative) }\end{array}$ & $\begin{array}{l}\$ 0.28 / \mathrm{Wdc} \\
\text { (installer) } \\
\$ 0.38 / \mathrm{Wdc} \\
\text { (integrator) }\end{array}$ & $\begin{array}{l}\text { General and administrative expenses- } \\
\text { including fixed overhead expenses } \\
\text { covering payroll (excluding permitting } \\
\text { payroll), facilities, administrative, finance, } \\
\text { legal, information technology, and other } \\
\text { corporate functions as well as office } \\
\text { expenses; adjusted based on state "cost of } \\
\text { doing business" index }\end{array}$ & Feldman et al. (2013) \\
\hline Profit (\%) & $17 \%$ & $\begin{array}{l}\text { Applies a fixed percentage margin to all } \\
\text { direct costs including hardware, installation } \\
\text { labor, direct sales and marketing, design, } \\
\text { installation, and permitting fees (note: } \\
\$ 0.19 / \text { Wdc of the total sales \& marketing } \\
\text { and overhead is classified as direct costs) }\end{array}$ & Chung et al. (2015) \\
\hline
\end{tabular}

\subsection{Residential Model Output}

Figure 12 presents the U.S. national benchmark from our residential model. The national benchmark represents an average weighted by 2015 state installed capacities. Market shares of $50 \%$ for installers and $50 \%$ for integrators are used to compute the national weighted average. String inverter, power optimizer, and microinverter options are each modeled individually, but the "Mixed" case applies their market shares (54\%, 22\%, and 24\%) as weightings.

Figure 13 presents the benchmark in the top U.S. solar markets (by 2015 installations), reflecting differences in supply chain and labor costs, sales tax, and selling, general, and administrative (SG\&A) expenses - that is, the cost of doing business (Case 2012). 


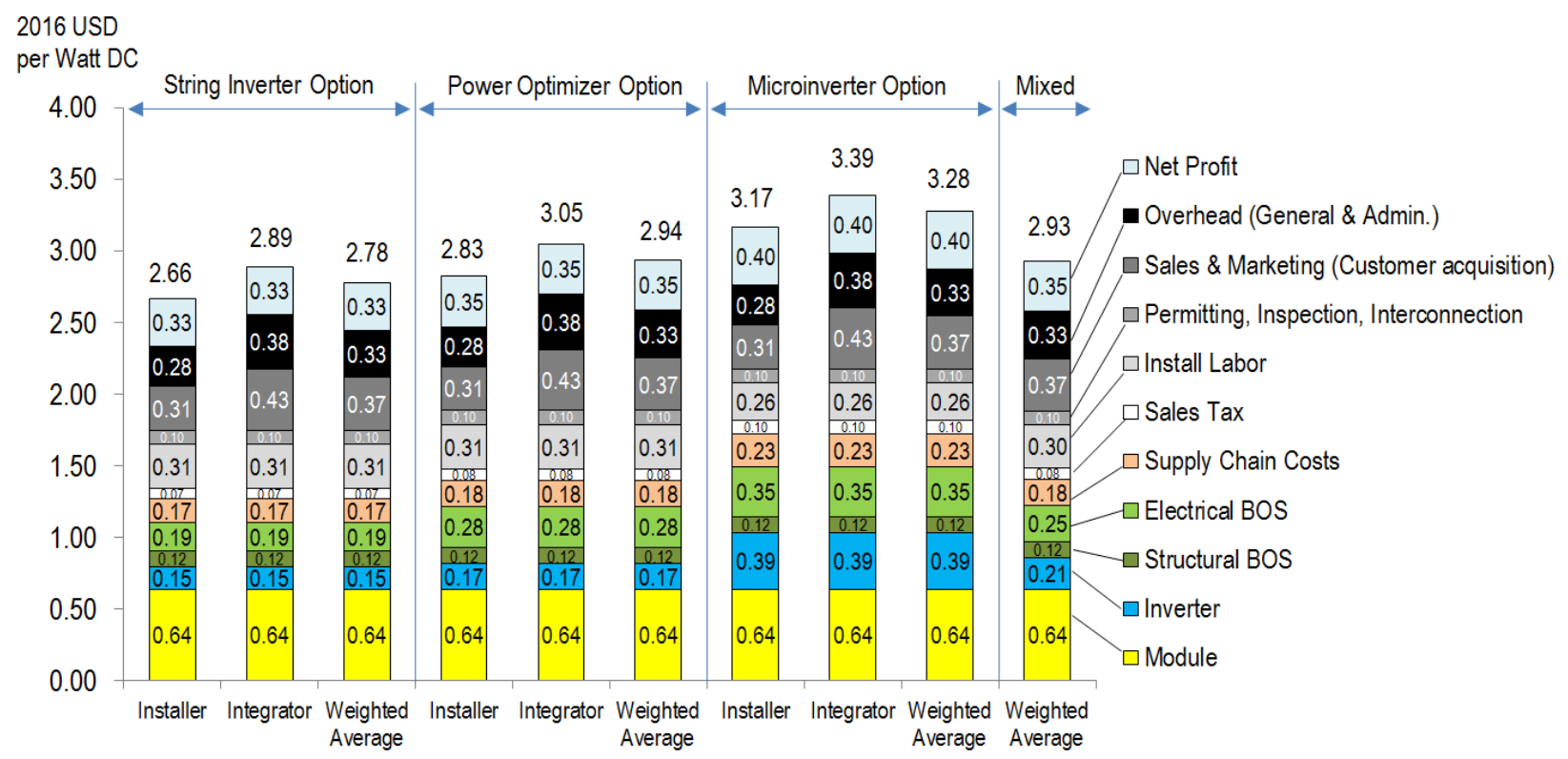

Figure 12. Q1 2016 U.S. benchmark: 5.6-kW residential system cost (2016 USD/Wdc)

2016 USD

per Watt DC

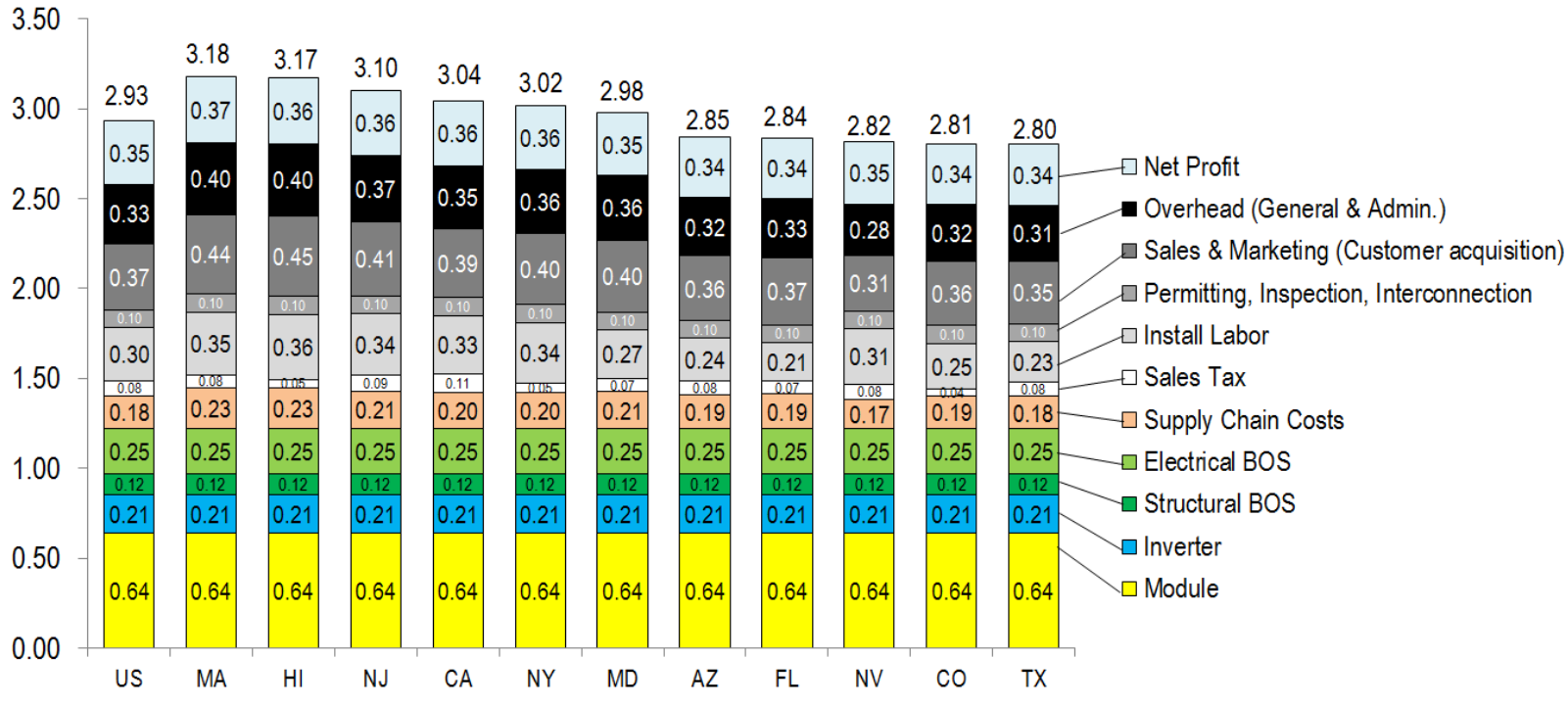

Figure 13. Q1 2016 benchmark by location: 5.6-kW residential system cost (2016 USD/Wdc) 


\subsection{Residential Model Output vs. Reported Costs}

In Figure 14, our bottom-up modeling approach yields a different cost structure than those reported by public solar integrators in their corporate filings (SolarCity 2016; Sunrun 2016; Vivint Solar 2016). Because integrators sell and lease PV systems, they practice a different method of reporting costs than businesses that only sell goods. Many of the costs for leased systems are reported over the life of the lease rather than the period in which the system is sold; therefore, it is difficult to determine the actual costs at the time of the sale. While the corporate filings from SolarCity, Sunrun, and Vivint Solar do report system costs on a quarterly basis, the lack of transparency in the public filings makes it difficult to determine the underlying costs as well as the timing of those costs. Also, the reported costs for SolarCity include residential and commercial systems, which skew the reported numbers slightly and does not yield a full one-toone correlation with our exclusively residential cost numbers.

Note also that the Q4 2015 reported costs are used here instead of Q1 2016 because the NEM reforms in several state markets, such as Nevada, slowed down residential PV integrator installation in Q1 2016 (shown in Figure 10) and then inflated the calculated cost from those companies' Q1 2016 filings. To remove the market and policy impacts from this comparison, we use the Q4 2015 reported costs.

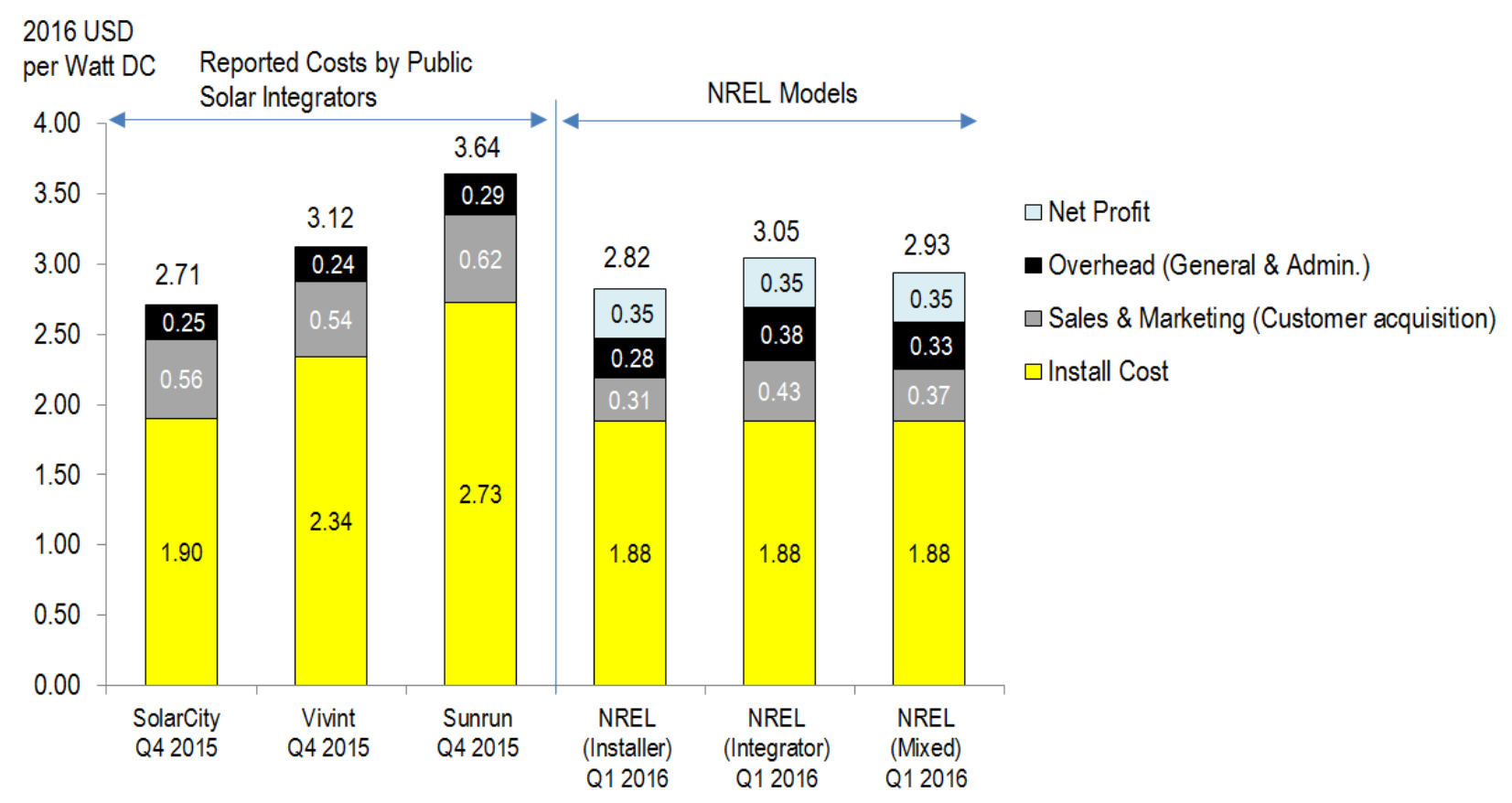

Figure 14. Q1 2016 NREL modeled cost benchmark (2016 USD/Wdc) vs. Q4 2015 companyreported costs 


\section{Commercial PV Model}

This section describes our commercial model's structure, inputs, and assumptions (Section 4.1) and output (4.2).

\subsection{Commercial Model Structure, Inputs, and Assumptions}

We model a 200-kW, 1,000 volts DC (Vdc), commercial-scale flat-roof system using multicrystalline $16.7 \%$-efficient modules from a Tier 1 supplier, three-phase string inverters, and a ballasted racking solution on a membrane roof. A penetrating PV mounting system can have higher energy yield ( $\mathrm{kWh}$ per $\mathrm{kW}$ ) owing to wider tilt-angle range allowance. However, we do not model this system type because its market share has declined due to additional required flashing and sealing work, roof warranty issues, and the relative difficulty of replacing such a system in the future. Figure 15 presents a schematic of our commercial-scale system cost model. Table 4 presents the detailed modeling inputs and assumptions. Also, we separate our cost estimate into EPC and project-development functions. While some firms engage in both activities in an integrated manner, and potentially achieve lower cost and pricing by reducing the total margin across functions, we believe the distinction can help separate and highlight the specific cost trends and drivers associated with each function.

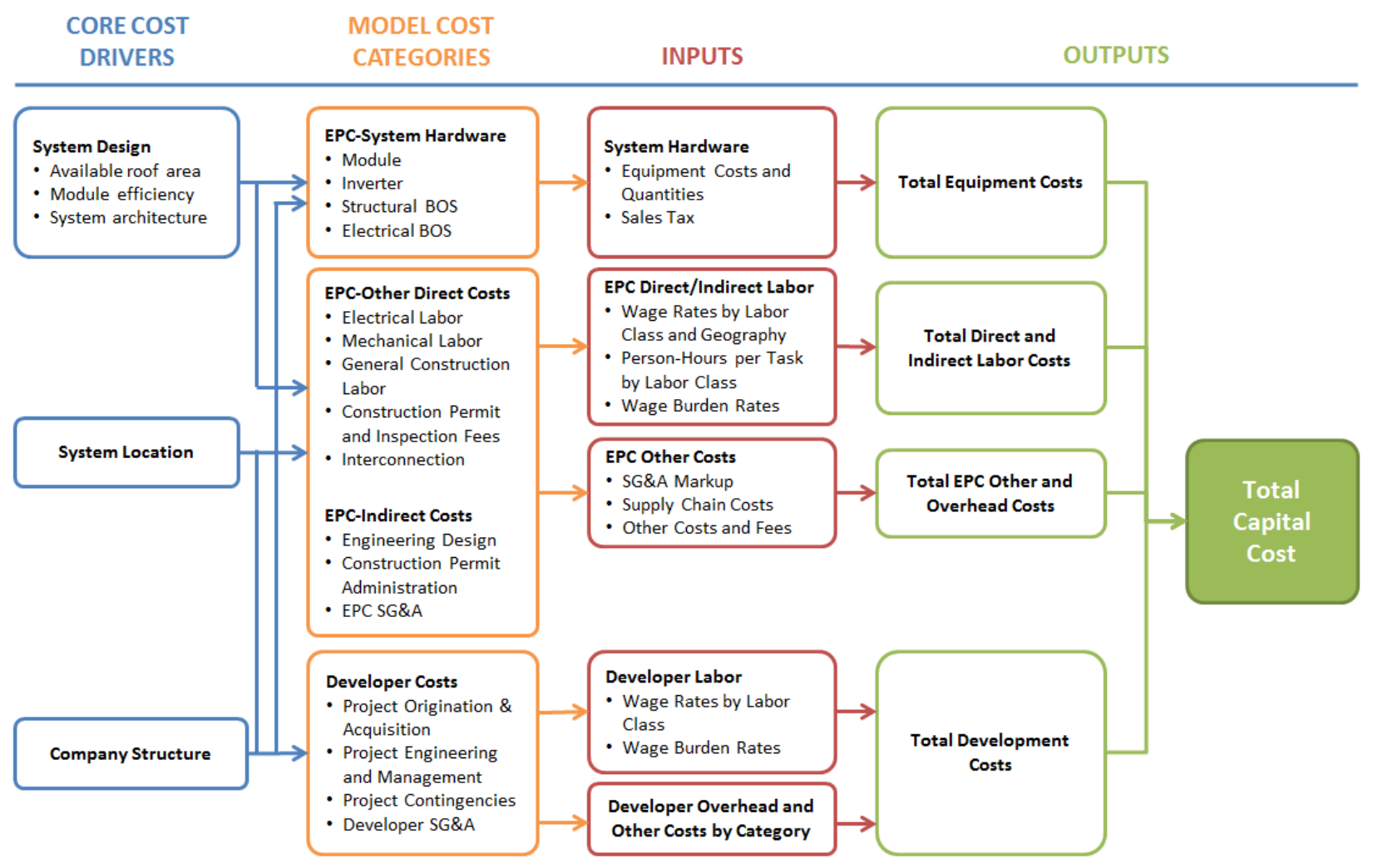

Figure 15. Commercial PV: model structure 
Table 4. Commercial PV: Modeling Inputs and Assumptions

\begin{tabular}{|c|c|c|c|}
\hline Category & Modeled Value & Description & Sources \\
\hline System size & $200 \mathrm{~kW}$ & Average installed size per system & Go Solar CA (2016) \\
\hline $\begin{array}{l}\text { Module } \\
\text { efficiency }\end{array}$ & $16.7 \%$ & Average module efficiency & Go Solar CA (2016) \\
\hline Module price & $\$ 0.64 / \mathrm{Wdc}$ & $\begin{array}{l}\text { Ex-factory gate (first buyer) ASP, Tier } 1 \\
\text { modules }\end{array}$ & $\begin{array}{l}\text { Bloomberg (2016), Mints } \\
\text { (2016), NREL (2016) }\end{array}$ \\
\hline Inverter price & $\$ 0.13 / \mathrm{Wac}$ & $\begin{array}{l}\text { Ex-factory gate prices (first buyer) ASP, } \\
\text { Tier } 1 \text { inverters }\end{array}$ & $\begin{array}{l}\text { NREL (2016), PVinsights } \\
(2016)\end{array}$ \\
\hline $\begin{array}{l}\text { Structural } \\
\text { components } \\
\text { (racking) }\end{array}$ & $\begin{array}{l}\$ 0.14-\$ 0.30 / \mathrm{Wdc} ; \\
\text { varies by location and } \\
\text { system size }\end{array}$ & $\begin{array}{l}\text { Ex-factory gate prices; flat-roof ballasted } \\
\text { racking system }\end{array}$ & $\begin{array}{l}\text { ASCE (2006), model } \\
\text { assumptions, NREL (2016) }\end{array}$ \\
\hline $\begin{array}{l}\text { Electrical } \\
\text { components }\end{array}$ & $\begin{array}{l}\text { Varies by location } \\
\text { and system size }\end{array}$ & $\begin{array}{l}\text { Conductors, conduit and fittings, } \\
\text { transition boxes, switchgear, panel } \\
\text { boards, etc. }\end{array}$ & $\begin{array}{l}\text { Model assumptions, NREL } \\
\text { (2016), RSMeans (2015) }\end{array}$ \\
\hline $\begin{array}{l}\text { EPC overhead } \\
\text { (\% of } \\
\text { equipment } \\
\text { costs) }\end{array}$ & $13 \%$ & $\begin{array}{l}\text { Costs and fees associated with EPC } \\
\text { overhead, inventory, shipping, and } \\
\text { handling }\end{array}$ & NREL (2016) \\
\hline Sales tax & Varies by location & $\begin{array}{l}\text { Sales tax on equipment costs; national } \\
\text { benchmark applies an average (by state) } \\
\text { weighted by } 2015 \text { installed capacities }\end{array}$ & $\begin{array}{l}\text { DSIRE (2016), RSMeans } \\
\text { (2015) }\end{array}$ \\
\hline $\begin{array}{l}\text { Direct } \\
\text { installation } \\
\text { labor }\end{array}$ & $\begin{array}{l}\text { Electrician: } \$ 19.01- \\
\$ 37.52 \text { per hour; } \\
\text { Laborer: } \$ 12.41- \\
\$ 24.63 \text { per hour; } \\
\text { Varies by location } \\
\text { and inverter option }\end{array}$ & $\begin{array}{l}\text { Modeled labor rate assumes non-union } \\
\text { labor and depends on state; national } \\
\text { benchmark uses weighted average of } \\
\text { state rates }\end{array}$ & BLS (2016), NREL (2016) \\
\hline $\begin{array}{l}\text { Burden rates } \\
\text { (\% of direct } \\
\text { labor) }\end{array}$ & $\begin{array}{l}\text { Total nationwide } \\
\text { average: } 31.8 \%\end{array}$ & $\begin{array}{l}\text { Workers compensation (state-weighted } \\
\text { average), federal and state } \\
\text { unemployment insurance, FICA, builders } \\
\text { risk, public liability }\end{array}$ & RSMeans (2015) \\
\hline PII & $\$ 0.04-\$ 0.05 / \mathrm{Wdc}$ & $\begin{array}{l}\text { For construction permits fee, } \\
\text { interconnection, testing, and } \\
\text { commissioning }\end{array}$ & NREL (2016) \\
\hline $\begin{array}{l}\text { Developer } \\
\text { overhead }\end{array}$ & $\begin{array}{l}\text { Assume 10-MW } \\
\text { system development } \\
\text { and installation per } \\
\text { year for a typical } \\
\text { developer }\end{array}$ & $\begin{array}{l}\text { Includes fixed overhead expenses such } \\
\text { as payroll, facilities, travel, insurance, } \\
\text { administrative, business development, } \\
\text { finance, and other corporate functions; } \\
\text { assumes } 10 \mathrm{MW} / \text { year of system sales }\end{array}$ & $\begin{array}{l}\text { Model assumptions, NREL } \\
\text { (2016) }\end{array}$ \\
\hline Contingency & $4 \%$ & $\begin{array}{l}\text { Estimated as markup on EPC price; } \\
\text { value represents actual cost overruns } \\
\text { above estimated price }\end{array}$ & NREL (2016) \\
\hline Profit & $2 \%$ & $\begin{array}{l}\text { Includes } 2 \% \text { EPC markup (bringing the } \\
\text { EPC total markup of overhead and profit } \\
\text { to } 15 \% \text { ) and a } 2 \% \text { markup on all } \\
\text { overhead costs }\end{array}$ & Feldman et al. (2013) \\
\hline
\end{tabular}




\subsection{Commercial Model Output}

Figure 16 presents the U.S. national benchmark from our commercial model. As in the residential model, the national benchmark represents an average weighted by 2015 state installed capacities. We model different system sizes because of the wide scope of the "commercial" sector, which comprises a diverse customer base occupying a variety of building sizes. Also, economies of scale — driven by hardware, labor, and related markups - are evident here. That is, as system sizes increase, the per-watt cost to build them decreases. Meanwhile, because we assume that a typical developer has $10 \mathrm{MW}$ of system development and installation per year, the developer overheads on this $10-\mathrm{MW}$ total capacity do not vary for different system sizes. When a developer installs more capacity annually, that developer's overhead per watt in each system declines (shown in Figure 18 in our Q1 2015 benchmark report, Chung et al. 2015).

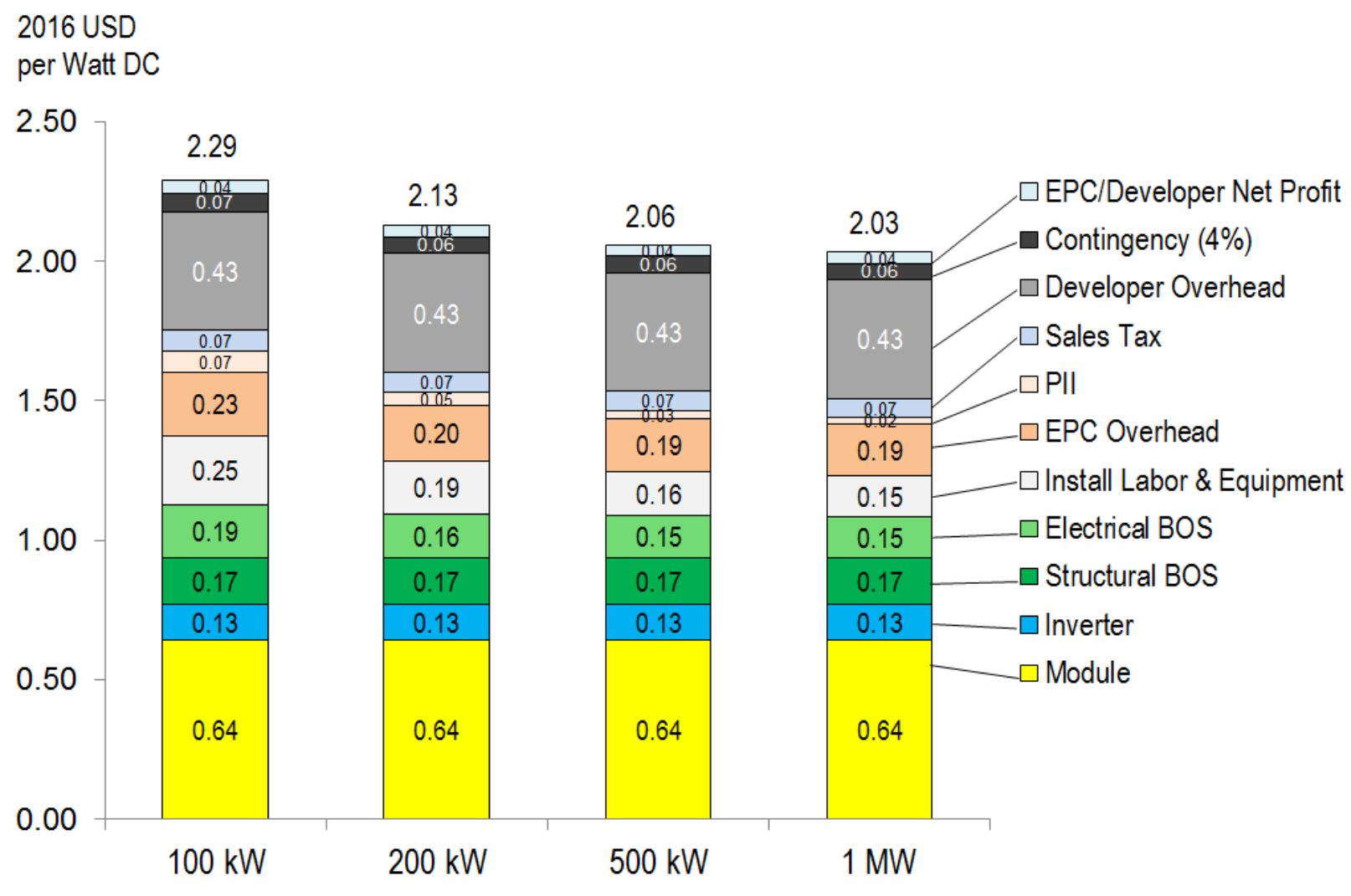

Figure 16. Q1 2016 U.S. benchmark: commercial system cost (2016 USD/Wdc)

Figure 17 presents the benchmark from our commercial model by location in the top U.S. solar markets (by 2015 installations). The main cost drivers for different regions in the commercial PV market are the same as in the residential model (labor rates, sales tax, and cost of doing business index) but also include costs associated with wind or snow loading. 


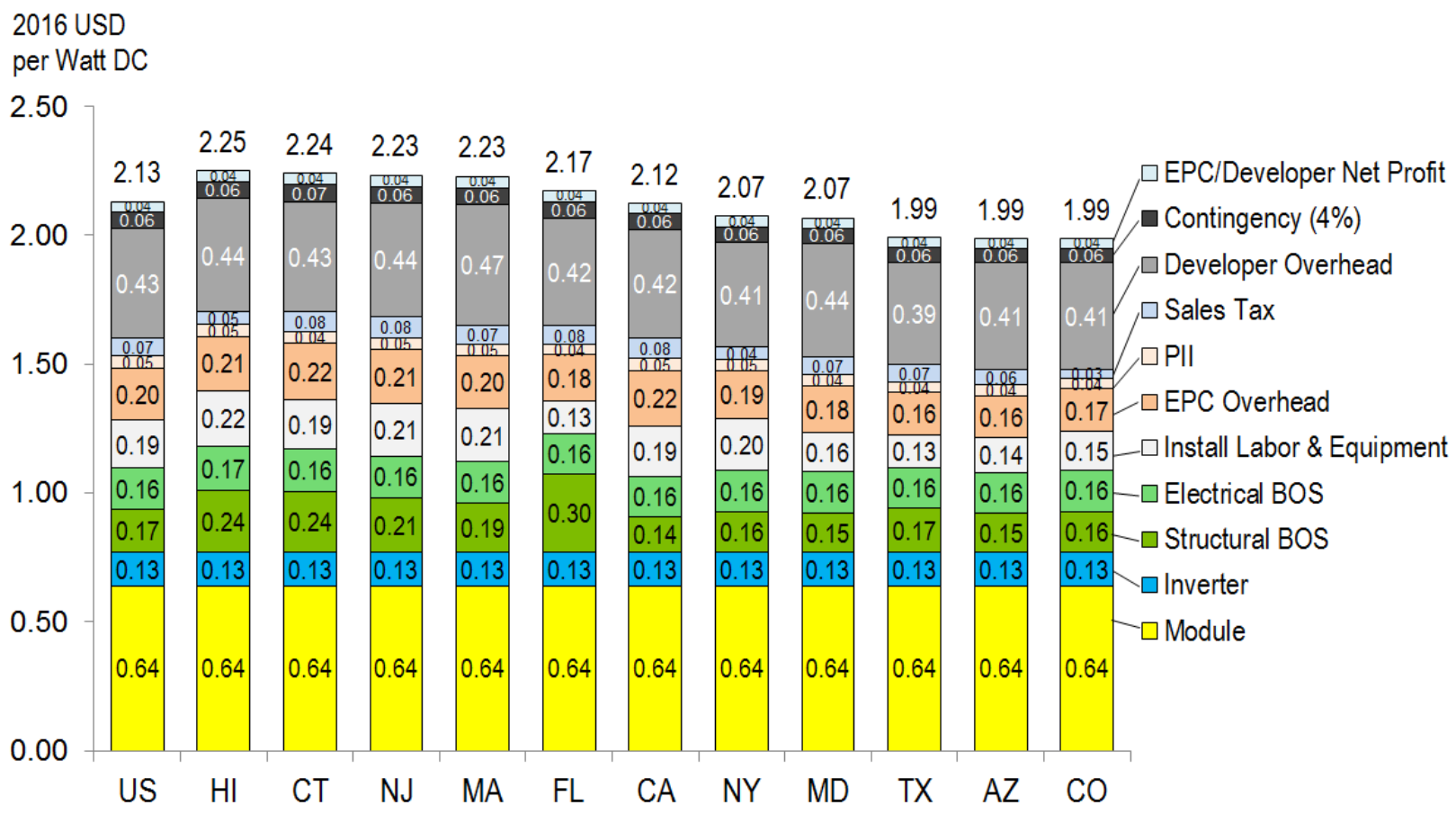

Figure 17. Q1 2016 benchmark by location: 200-kW commercial system cost (2016 USD/Wdc) 


\section{Utility-Scale PV Model}

This section describes our utility-scale model's structure, inputs, and assumptions (Section 5.1) and output (5.2).

\subsection{Utility-Scale Model Structure, Inputs, and Assumptions}

We model a 100-MW, 1,000-Vdc utility-scale system using 72-cell, multicrystalline 16.7\%efficient modules from a Tier 1 supplier and three-phase central inverters. We model both fixedtilt and one-axis tracking on ground-mounted racking systems using driven-pile foundations. Similarly, we separate our cost estimate into EPC and project-development functions. While some firms engage in both activities in an integrated manner, we believe the distinction can help separate and highlight the specific cost trends and drivers associated with each function.

Figure 18 presents a schematic of our utility-scale system cost model, and Table 5 details its assumptions and inputs.

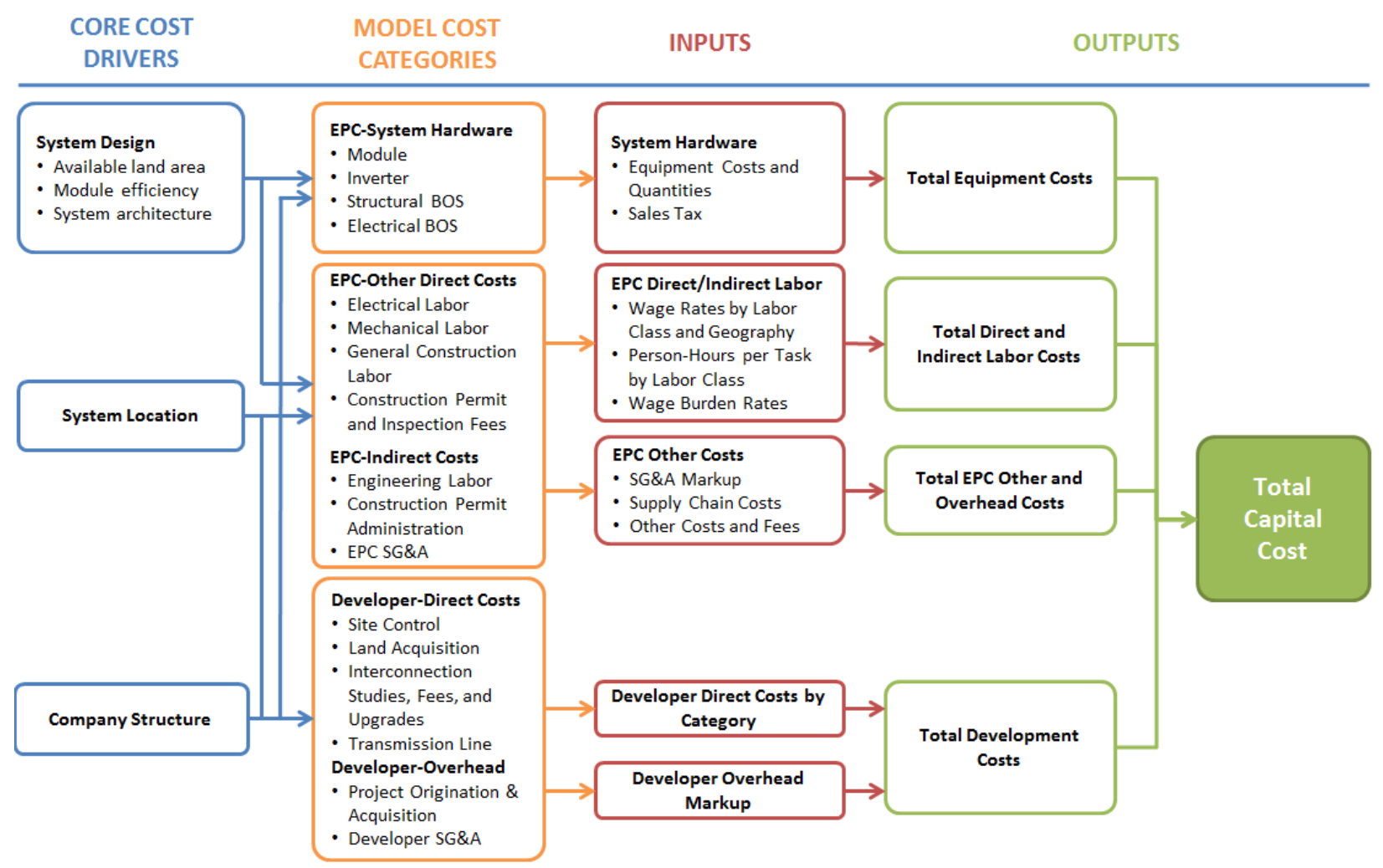

Figure 18. Utility-scale PV: model structure 
Table 5. Utility-Scale PV: Modeling Inputs and Assumptions

\begin{tabular}{|c|c|c|c|}
\hline Category & Modeled Value & Description & Sources \\
\hline System size & $100 \mathrm{MW}$ & $\begin{array}{l}\text { A large utility-scale system } \\
\text { capacity }\end{array}$ & Model assumption \\
\hline $\begin{array}{l}\text { Module } \\
\text { efficiency }\end{array}$ & $16.7 \%$ & Average module efficiency & NREL (2016) \\
\hline Module price & $\$ 0.64 / \mathrm{Wdc}$ & $\begin{array}{l}\text { Ex-factory gate (first buyer) } \\
\text { ASP, Tier } 1 \text { modules }\end{array}$ & $\begin{array}{l}\text { Bloomberg (2016), Mints (2016), } \\
\text { NREL (2016) }\end{array}$ \\
\hline \multirow{4}{*}{ Inverter price } & \multirow{4}{*}{$\begin{array}{l}\$ 0.09 / \mathrm{Wdc} \text { (fixed- } \\
\text { tilt) } \\
\$ 0.10 / \mathrm{Wdc} \text { (one- } \\
\text { axis tracker) }\end{array}$} & $\begin{array}{l}\text { Ex-factory gate prices (first } \\
\text { buyer) ASP, Tier } 1 \text { inverters }\end{array}$ & \multirow{4}{*}{ NREL (2016), PVinsights (2016) } \\
\hline & & DC-to-AC ratio $=120 \%$ for & \\
\hline & & one-axis tracker & \\
\hline & & $\begin{array}{l}\text { DC-to-AC ratio }=140 \% \text { for } \\
\text { fixed-tilt }\end{array}$ & \\
\hline $\begin{array}{l}\text { Structural } \\
\text { components } \\
\text { (racking) }\end{array}$ & $\begin{array}{l}\$ 0.14-\$ 0.30 / \mathrm{Wdc} \\
\text { varies by location } \\
\text { and system size }\end{array}$ & $\begin{array}{l}\text { Ex-factory gate prices; fixed-tilt } \\
\text { racking or one-axis tracking } \\
\text { system }\end{array}$ & $\begin{array}{l}\text { ASCE (2006), model } \\
\text { assumptions, NREL (2016) }\end{array}$ \\
\hline $\begin{array}{l}\text { Electrical } \\
\text { components }\end{array}$ & $\begin{array}{l}\text { Varies by location } \\
\text { and system size }\end{array}$ & $\begin{array}{l}\text { Conductors, conduit and } \\
\text { fittings, transition boxes, } \\
\text { switchgear, panel boards, } \\
\text { onsite transmission, etc. }\end{array}$ & $\begin{array}{l}\text { Model assumptions, NREL } \\
\text { (2016), RSMeans (2015) }\end{array}$ \\
\hline
\end{tabular}

$8.67 \%-13 \%$ for equipment and material (except EPC for transmission overhead (\% line costs); $23 \%$ of equipment $69 \%$ for labor costs) costs; varies by system size, labor activity, and location

Sales tax Varies by location

Electrician: \$19.01-\$37.52 per hour;

Direct installation labor

Laborer: \$12.41$\$ 24.63$ per hour; Varies by location and inverter option

Burden rates (\% of direct labor)
Total nationwide average: $31.8 \%$
National benchmark applies an average (by state) weighted by 2015 installed capacities

Costs associated with EPC

SG\&A, warehousing, shipping, NREL (2016) and logistics
Modeled labor rate assumes non-union and union labor and depends on state; national benchmark uses weighted average of state rates
DSIRE (2016), RSMeans (2015)

BLS (2016), NREL (2016)
Workers compensation (stateweighted average), federal and state unemployment insurance, FICA, builders risk, public liability
RSMeans (2015) 


\begin{tabular}{|c|c|c|c|}
\hline Category & Modeled Value & Description & Sources \\
\hline PII & $\begin{array}{l}\$ 0.03-0.09 / \mathrm{Wdc} \\
\text { Varies by system } \\
\text { size and location }\end{array}$ & $\begin{array}{l}\text { For construction permits fee, } \\
\text { interconnection, testing, and } \\
\text { commissioning }\end{array}$ & NREL (2016) \\
\hline $\begin{array}{l}\text { Transmission } \\
\text { line } \\
\text { (gen-tie line) }\end{array}$ & $\begin{array}{l}\$ 0.00-0.02 / \mathrm{Wdc} \\
\text { Varies by system } \\
\text { size }\end{array}$ & $\begin{array}{l}\text { System size < } 10 \mathrm{MW} \text {, use } 0 \\
\text { mile; } \\
\text { System size }>200 \mathrm{MW} \text {, use } 5 \\
\text { miles } \\
10-200 \mathrm{MW} \text {, use linear } \\
\text { interpolation }\end{array}$ & $\begin{array}{l}\text { Model assumptions, NREL } \\
(2016)\end{array}$ \\
\hline $\begin{array}{l}\text { Developer } \\
\text { overhead }\end{array}$ & $\begin{array}{l}3 \%-12 \% \\
\text { Varies by system } \\
\text { size (100 MW } \\
\text { uses } 3 \% ; 5 \mathrm{MW} \\
\text { uses } 12 \%)\end{array}$ & $\begin{array}{l}\text { Includes overhead expenses } \\
\text { such as payroll, facilities, } \\
\text { travel, legal fees, } \\
\text { administrative, business } \\
\text { development, finance, and } \\
\text { other corporate functions }\end{array}$ & $\begin{array}{l}\text { Model assumptions, NREL } \\
(2016)\end{array}$ \\
\hline Contingency & $3 \%$ & $\begin{array}{l}\text { Estimated as markup on EPC } \\
\text { cost }\end{array}$ & NREL (2016) \\
\hline Profit & $\begin{array}{l}1.33 \%-2 \% \\
\text { Varies by system } \\
\text { size }(100 \mathrm{MW} \\
\text { uses } 1.33 \% ; 5 \\
\text { MW uses } 2 \%)\end{array}$ & $\begin{array}{l}\text { Includes EPC markup (bringing } \\
\text { the EPC total markup of } \\
\text { overhead and profit to } 10 \%- \\
15 \% \text { ) as well as a markup on } \\
\text { all overhead costs; } 5 \mathrm{MW} \\
\text { system profit margin consistent } \\
\text { with commercial market } \\
\text { assumptions; larger system } \\
\text { profit scale-down consistent } \\
\text { with EPC overhead and profit } \\
\text { scale-down from } 15 \% \text { to } 10 \%\end{array}$ & $\begin{array}{l}\text { Feldman et al. (2013), model } \\
\text { assumptions, NREL (2016) }\end{array}$ \\
\hline
\end{tabular}

Although EPCs and developers tend to employ low-cost, non-union labor (based on data from BLS 2016) for PV system construction when possible, union labor is sometimes mandated. Construction trade unions may negotiate with the local jurisdiction and EPC/developer during the public review period of the permitting process. Figure 19 shows 2015 utility-scale PV capacity installed (GTM Research and SEIA 2016) and the proportion of unionized labor in each state (BLS 2016). The unionized labor number represents the percentage of employed workers in each state's entire construction industry who are union members. In our utility-scale model, both non-union and union labor rates are considered (Figure 20). 


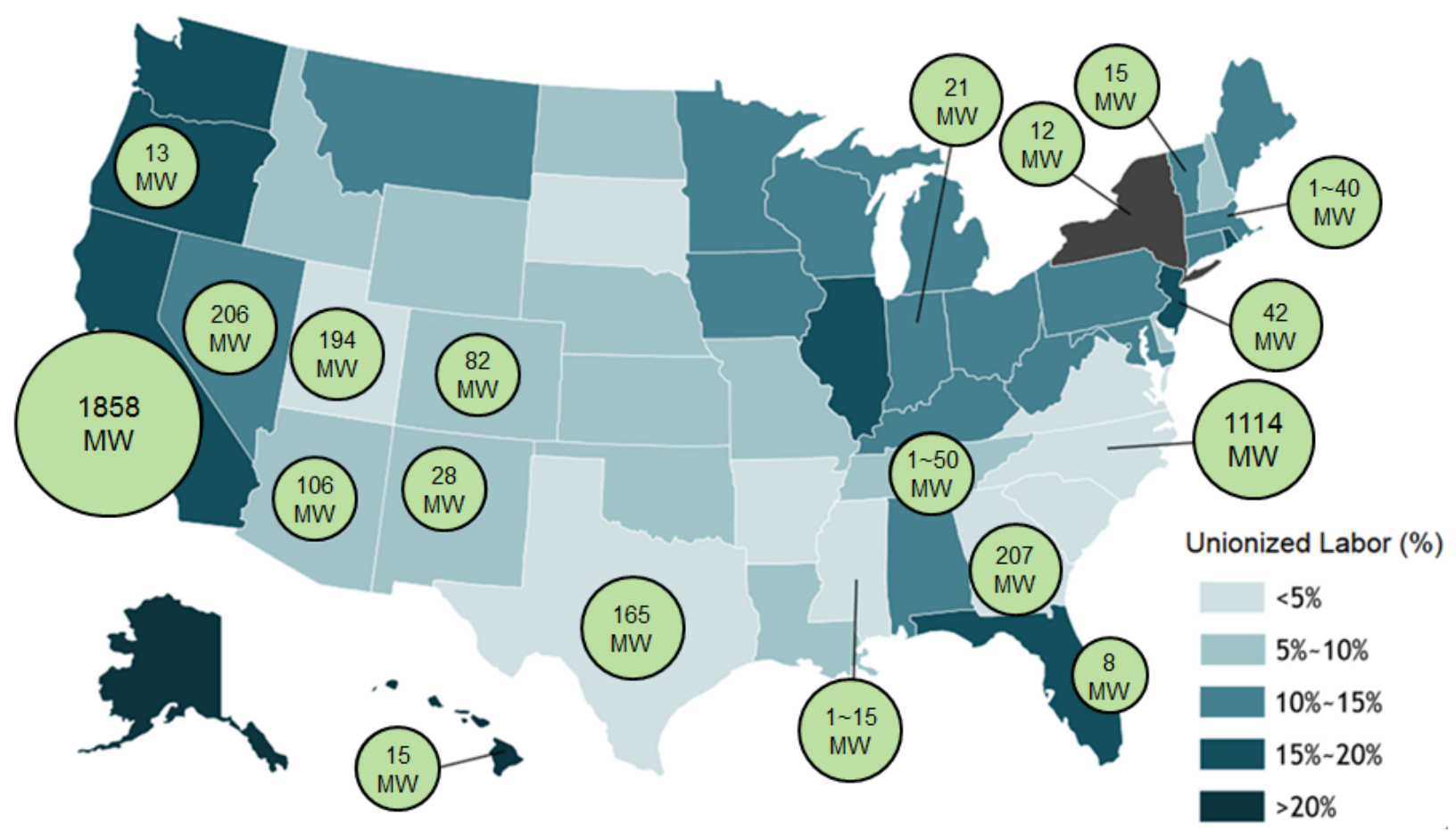

Figure 19. Utility-scale PV: 2015 capacity installed and percentage of unionized labor by state (BLS 2016; GTM Research and SEIA 2016)

\subsection{Utility-Scale Model Output}

Figure 20 presents the regional EPC benchmark from our utility-scale model, and Figure 21 presents the U.S. national benchmark (EPC + developer) for fixed-tilt and one-axis tracker systems, using non-union labor. In Figure 21, note the following:

1. The national benchmark applies an average weighted by 2015 installed capacities.

2. Non-union labor is used.

3. Economies of scale - driven by BOS, labor, related markups, and development cost - are demonstrated. 


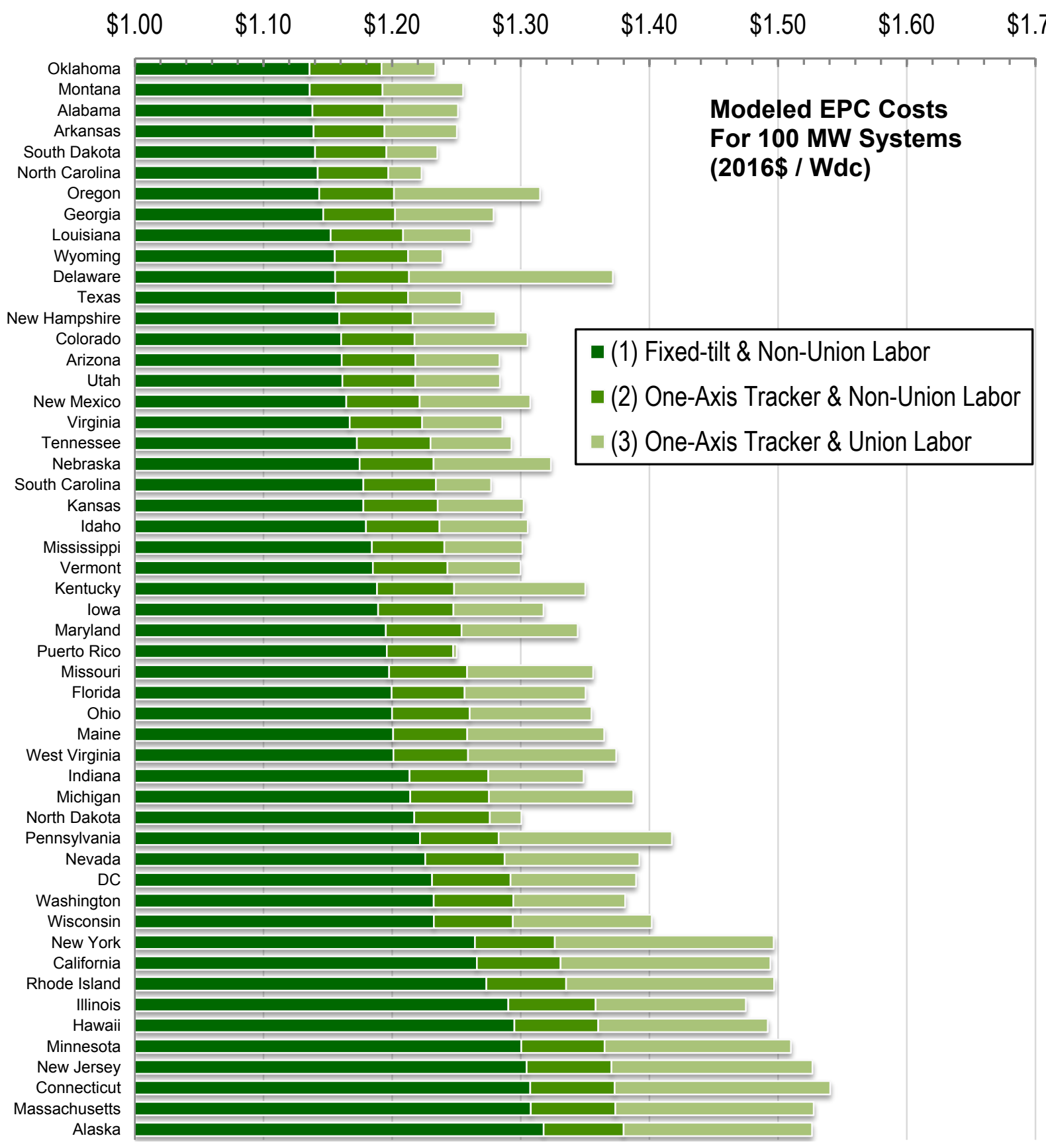

Figure 20. Q1 2016 benchmark by location: 100-MW utility-scale PV systems, EPC only (2016 USD/Wdc) ${ }^{9}$

\footnotetext{
${ }^{9}$ The fixed-tilt, non-union cost is always lowest, followed by the one-axis tracker, non-union cost and the one-axis tracker, union cost. Thus, the bars are additive: the fixed-tilt, non-union cost is represented by the dark green bar alone; the one-axis tracker, non-union cost is the sum of the dark green and medium green bars; and the one-axis tracker, union cost is the sum of all three bars.
} 


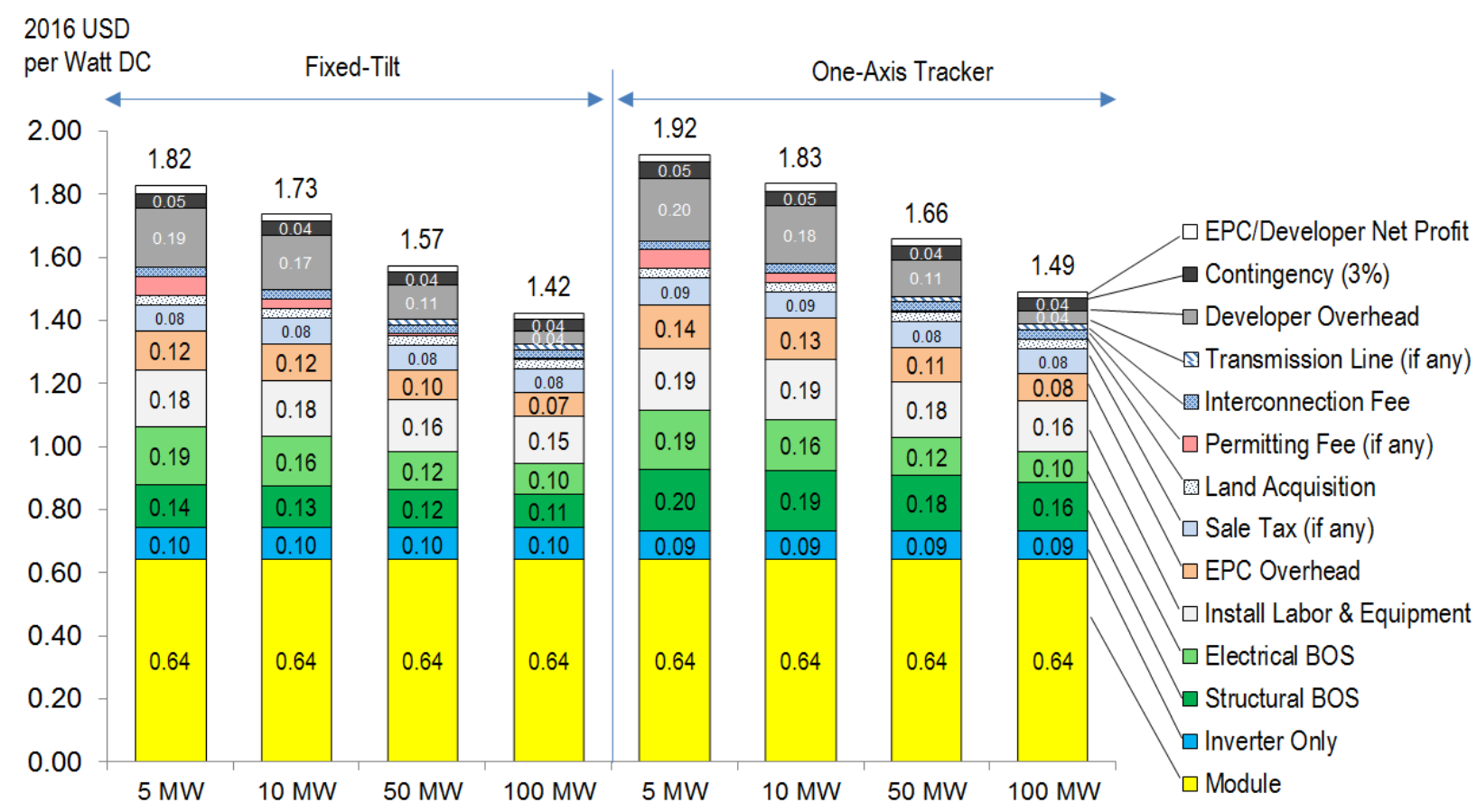

Figure 21. Q1 2016 U.S. benchmark: utility-scale PV total cost (EPC + developer) 2016 USD/Wdc 


\section{Model Applications}

This section includes three additional applications of our cost modeling: system cost reduction from economies of scale (Section 6.1), module efficiency impacts (6.2), and regional LCOE (6.3). The granularity of our bottom-up models enables us to determine the changes in particular cost drivers over time. Accordingly, the models can be used to predict future system costreduction opportunities based on particular market trends and technologies.

\subsection{System Cost Reduction from Economies of Scale}

Figure 22 demonstrates the cost savings from different system configurations - scaling up system size from $10 \mathrm{MW}$ to $100 \mathrm{MW}$ can gain savings from BOS bulk price, labor learning curve, and lower developer overhead. Note that non-union labor is used in this figure.

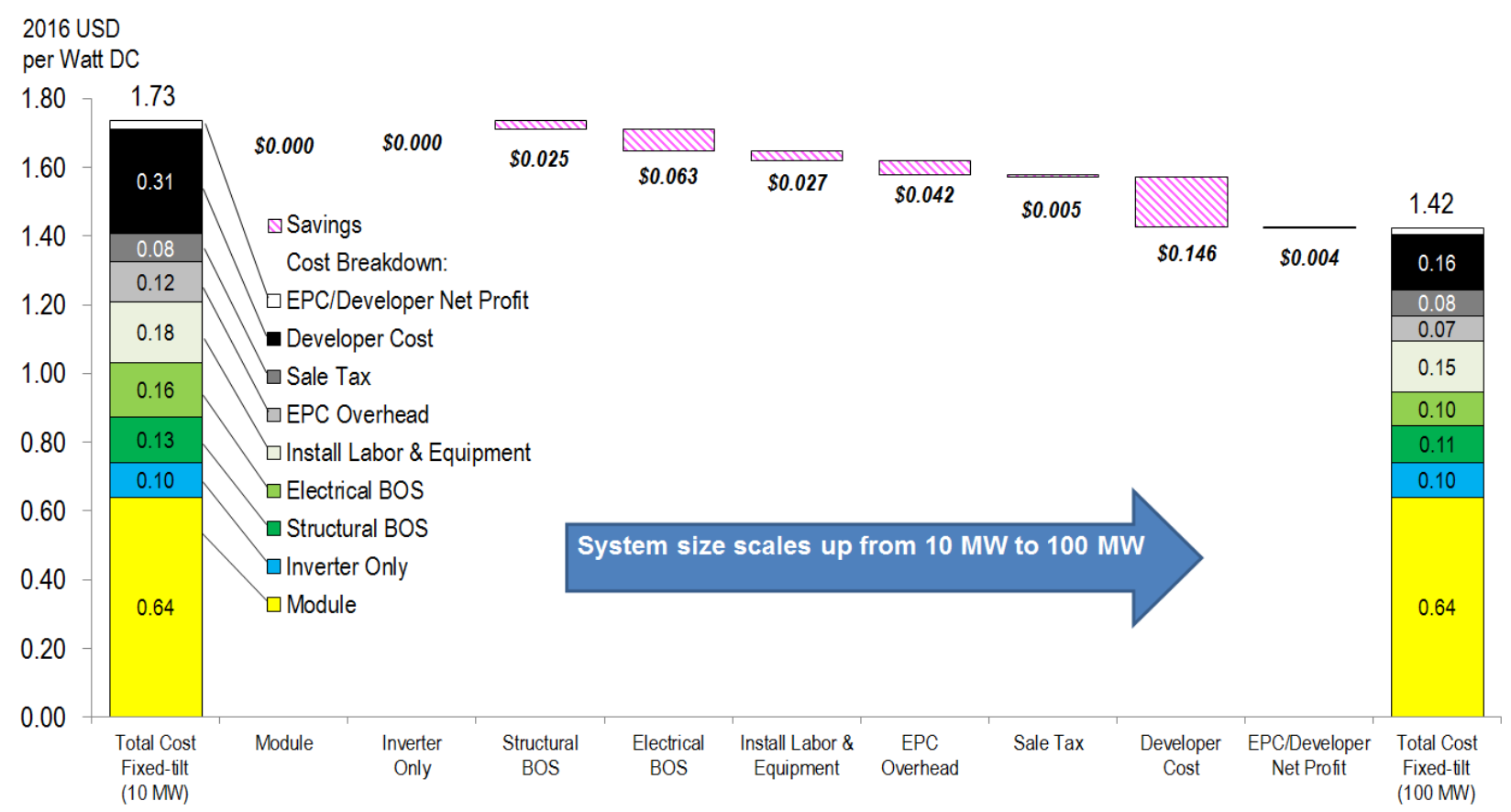

Figure 22. Model application: U.S. utility-scale fixed-tilt PV system cost reduction from economies of scale (2016 USD/Wdc)

\subsection{Module Efficiency Impacts}

Our system cost models can also assess the economic benefits of high module efficiency. Because higher module efficiency reduces the number of modules required to reach a certain system size, the related racking or mounting hardware, foundation, BOS, EPC/developer overhead, and labor hours are reduced accordingly. Figure 23 presents the relation between module efficiency and installed cost (with module prices held equal for any given efficiency) and demonstrates the cost-reduction potential due to high module efficiency. 


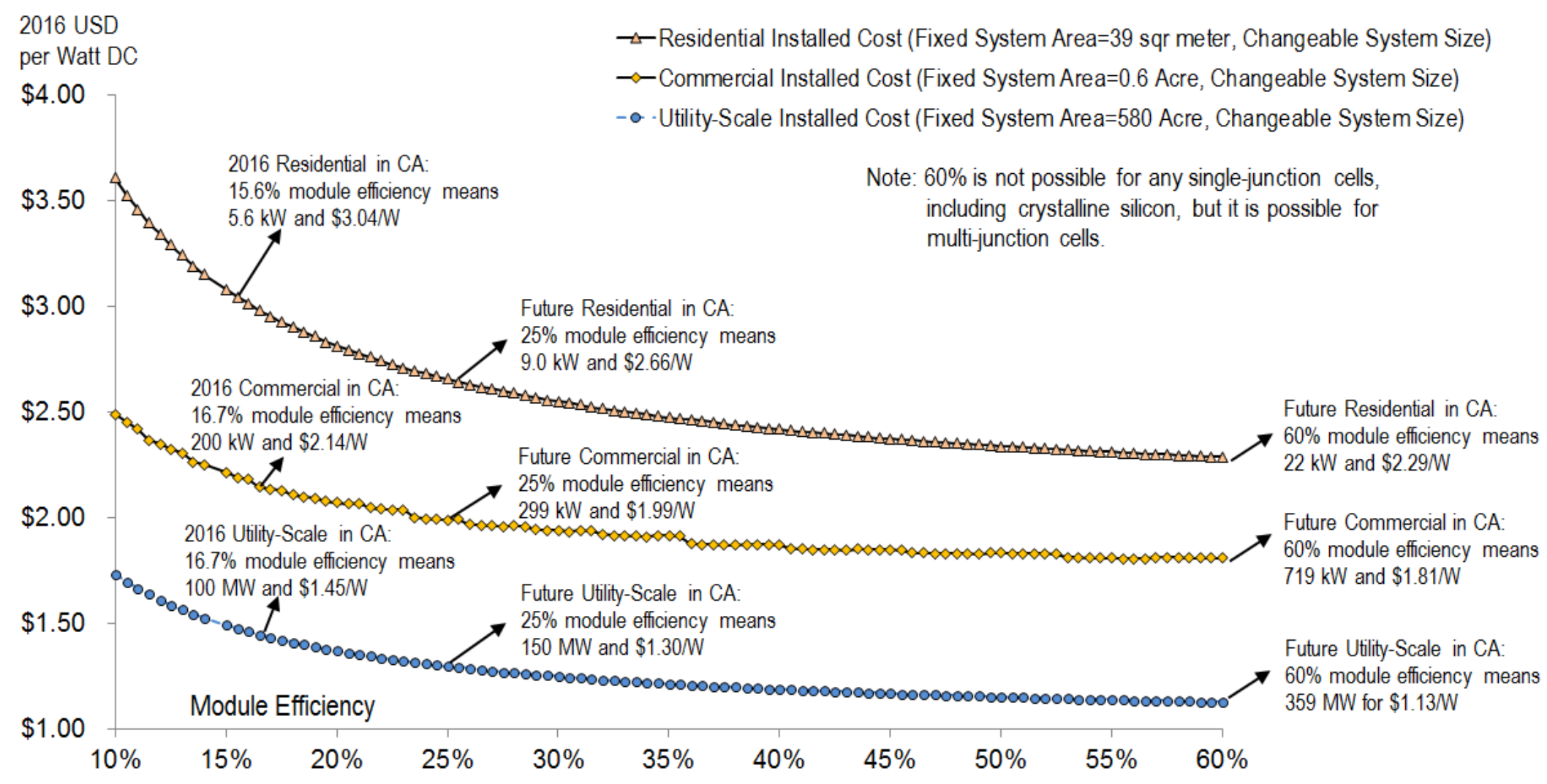

Figure 23. Modeled impacts of module efficiency on total system costs, 2016 


\subsection{Regional LCOE}

To estimate regional LCOEs across the United States, we combine modeled regional installed costs with localized solar irradiance and weather data, a PV performance model, and a pro forma financial analysis that models the revenue, operating expenses, taxes, incentives, debt structures, and cash flows for a representative PV system. We use NREL's System Advisor Model (SAM), a performance and financial model, ${ }^{10}$ to estimate location-specific hourly energy output over the PV system's lifetime and subsequently calculate the resulting real LCOEs (considering inflation) for each location. Figure 24 presents real LCOEs for a 100-MW utility-scale PV system with fixed-tilt or one-axis tracking based on regional labor and material costs, wind speeds, snow loading, solar irradiance, weather data, and sales tax. We assume the following:

- Investment tax credit $=30 \%$

- Discount rate $=$ target internal rate of return $=7 \%(\mathrm{Fu}$ et al. $2015 \mathrm{a})$

- Inflation $=$ escalator $=2.5 \%$

- Analysis period $=30$ years (thus power-purchase agreement $=$ LCOE for both real and nominal cases)

- Degradation rate $=0.5 \% /$ year

- For fixed-tilt: DC-to-AC ratio $=1.40$ and fixed operations and maintenance cost $=$ $\$ 15 / \mathrm{kW}$ per year

- For one-axis tracker: $\mathrm{DC}$-to-AC ratio $=1.20$ and fixed operations and maintenance $\operatorname{cost}=$ $\$ 18 / \mathrm{kW}$ per year.

Other, detailed SAM inputs can be found in our previous utility-scale PV work (Fu et al. 2015a).

${ }^{10}$ See https://sam.nrel.gov/. 


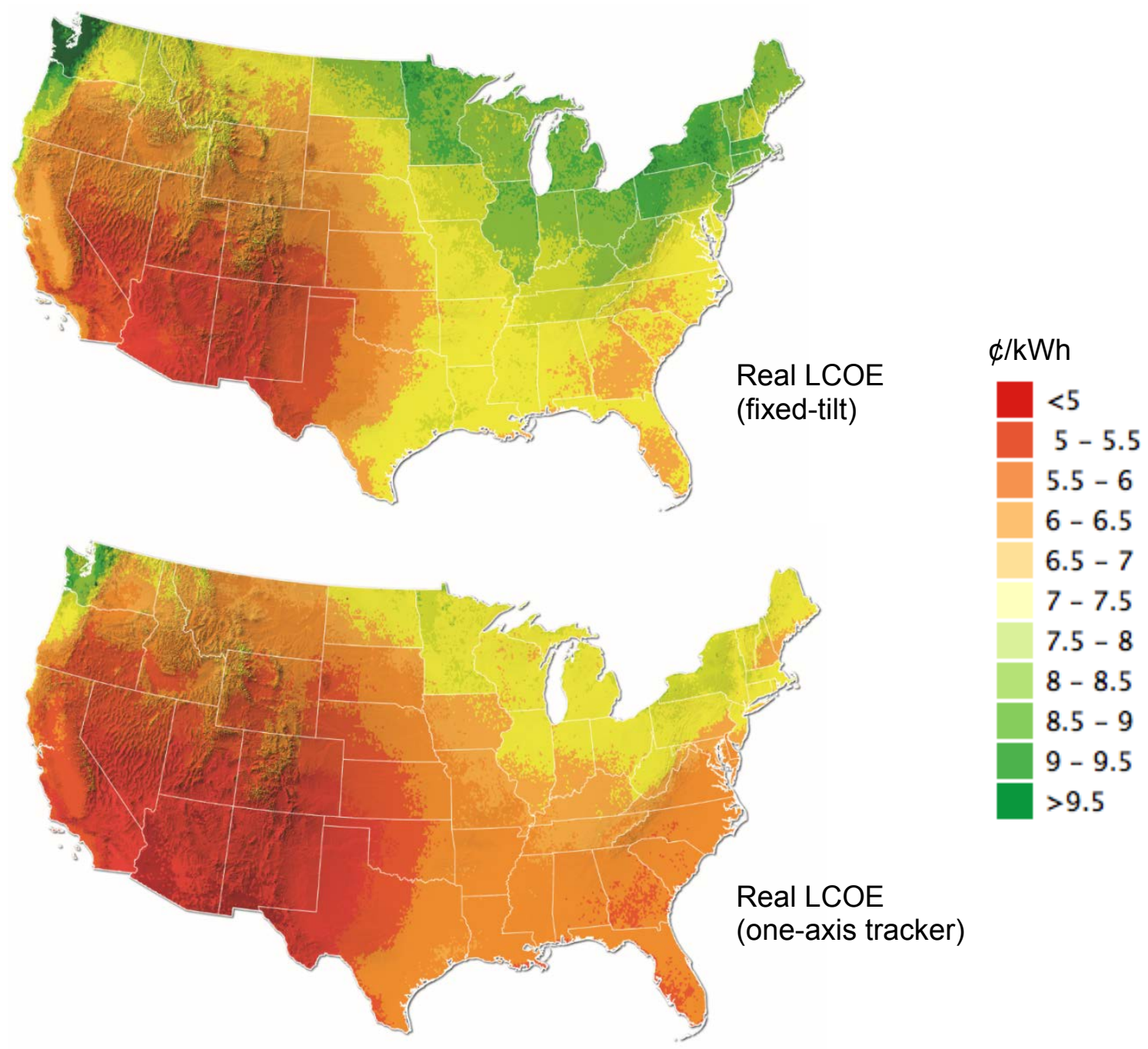

\begin{tabular}{|c|c|c|c|c|c|c|c|c|c|c|}
\hline \multirow[b]{2}{*}{ State } & \multirow[b]{2}{*}{ Location } & \multicolumn{3}{|c|}{ Fixed-Tilt } & \multicolumn{3}{|c|}{ One-Axis Tracker } & \multicolumn{3}{|c|}{ One-Axis Tracker vs. Fixed-Tilt } \\
\hline & & \begin{tabular}{|l} 
Total Installed \\
Costs $(\$ / W)$
\end{tabular} & $\begin{array}{l}\text { Nominal LCOE } \\
\text { ( } \$ \text { cent per } \mathrm{kWh} \text { ) }\end{array}$ & $\begin{array}{l}\text { Real LCOE } \\
\text { (cent per kWh) }\end{array}$ & \begin{tabular}{|l} 
Total Installed \\
Costs $(\$ / W)$
\end{tabular} & $\begin{array}{l}\text { Nominal LCOE } \\
\text { ( } \$ \text { cent per } \mathrm{kWh} \text { ) }\end{array}$ & $\begin{array}{l}\text { Real LCOE } \\
\text { (cent per kWh) }\end{array}$ & $\begin{array}{l}\text { Installed Costs } \\
\text { Premium (\%) }\end{array}$ & $\begin{array}{l}\text { Nominal LCOE } \\
\text { Change }(\%)\end{array}$ & $\begin{array}{l}\text { Real LCOE } \\
\text { Change (\%) }\end{array}$ \\
\hline $\mathrm{CA}$ & Bakersfield & 1.45 & 7.94 & 6.02 & 1.52 & 6.50 & 4.93 & $4.74 \%$ & $-18.14 \%$ & $-18.11 \%$ \\
\hline $\mathrm{CA}$ & Imperial & 1.45 & 7.19 & 5.45 & 1.52 & 5.80 & 4.40 & $4.74 \%$ & $-19.33 \%$ & $-19.27 \%$ \\
\hline$A Z$ & Prescott & 1.33 & 7.03 & 5.33 & 1.39 & 5.55 & 4.21 & $4.87 \%$ & $-21.05 \%$ & $-21.01 \%$ \\
\hline$A Z$ & Tucson & 1.33 & 6.78 & 5.14 & 1.39 & 5.38 & 4.08 & $4.87 \%$ & $-20.65 \%$ & $-20.62 \%$ \\
\hline NV & Las Vegas & 1.40 & 7.03 & 5.33 & 1.47 & 5.59 & 4.24 & $5.05 \%$ & $-20.48 \%$ & $-20.45 \%$ \\
\hline NM & Albuquerque & 1.33 & 6.84 & 5.19 & 1.40 & 5.52 & 4.19 & $5.15 \%$ & $-19.30 \%$ & $-19.27 \%$ \\
\hline $\mathrm{cO}$ & Alamosa & 1.33 & 6.85 & 5.19 & 1.39 & 5.43 & 4.11 & $4.51 \%$ & $-20.73 \%$ & $-20.81 \%$ \\
\hline NC & Jacksonville & 1.31 & 8.10 & 6.14 & 1.37 & 7.21 & 5.47 & $4.49 \%$ & $-10.99 \%$ & $-10.91 \%$ \\
\hline$T X$ & San Antonio & 1.32 & 8.02 & 6.08 & 1.38 & 6.82 & 5.17 & $4.55 \%$ & $-14.96 \%$ & $-14.97 \%$ \\
\hline NJ & Newark & 1.49 & 9.98 & 7.57 & 1.56 & 8.67 & 6.57 & $4.58 \%$ & $-13.13 \%$ & $-13.21 \%$ \\
\hline $\mathrm{FL}$ & Orlando & 1.37 & 9.01 & 6.83 & 1.43 & 7.68 & 5.82 & $4.61 \%$ & $-14.76 \%$ & $-14.79 \%$ \\
\hline $\mathrm{HI}$ & Kona & 1.48 & 8.63 & 6.54 & 1.55 & 7.41 & 5.61 & $4.73 \%$ & $-14.14 \%$ & $-14.22 \%$ \\
\hline
\end{tabular}

Figure 24. Modeled real LCOE ( $\phi / k W h)$ for a 100-MWdc utility-scale PV system with fixed-tilt and one-axis tracking in 2016 


\section{Conclusions}

Based on our bottom-up modeling, the Q1 2016 PV cost benchmarks are \$2.93/Wdc for residential systems, $\$ 2.13 / \mathrm{Wdc}$ for commercial systems, $\$ 1.42 / \mathrm{Wdc}$ (or $\$ 1.99 / \mathrm{Wac}$ ) for fixed-tilt utility-scale systems, and $\$ 1.49 / \mathrm{Wdc}$ (or $\$ 1.79 / \mathrm{Wac}$ ) for one-axis-tracking utility-scale systems. Overall, modeled PV installed costs continued to decline in Q1 2016 for all three sectors.

Figure 25 puts our Q1 2016 benchmark results in context with the results of previous NREL benchmarking analyses. When comparing the results across this period, note that:

1. Values are inflation adjusted using the U.S. Bureau of Labor Statistics' Consumer Price Index. Thus, historical values from our models are adjusted and presented as real USD instead of as nominal USD.

2. Cost categories are aggregated for comparison purposes. For instance, "Soft Costs - Others" represents PII, land acquisition, sales tax, and EPC/developer overhead and profit. ${ }^{11}$

3. Large differences between Q1 2015 and Q1 2016 in the utility-scale sectors and between Q4 2013 and Q1 2015 in the commercial sector were caused by model changes, such as amplifying economies of scale impacts on EPC contractor and developer costs. The changes between Q1 2015 and Q1 2016 are presented in Table 6.

In Q1 2016, the year-to-year nominal cost declines before model changes are \$0.15/Wdc (residential), \$0.07/Wdc (commercial), and \$0.08/Wdc (utility-scale). Lower module and inverter prices contributed to these cost reductions. Increased competition, lower installer and developer overheads, improved labor productivity, and optimized system configurations also contributed, particularly for EPC firms building commercial and utility-scale projects.

As Figure 25 shows, hardware cost reductions (module and inverter prices, in particular) were an even more important driver of system cost reductions in earlier years, but the size of these gains has decreased recently. This has increased the importance of non-hardware, or "soft" costs. ${ }^{12}$ Figure 26 shows the growing contribution from soft costs, particularly in the residential and commercial sectors. ${ }^{13}$ Soft costs and hardware costs also interact with each other. For instance, module efficiency improvements have reduced the number of modules required to construct a system of a given size, thus reducing hardware costs, and this trend has also reduced soft costs from direct labor and related installation overhead.

Finally, our results model "typical" systems across states and the entire country. When making more detailed comparisons in our models, cost differences due to regional variations, system configurations (such as MLPE vs. non-MLPE, fixed-tilt vs. one-axis tracker, and small vs. large system size), and business structures (such as installer vs. integrator, and EPC vs. developer) are considered. Different scenarios result in different costs, so consistent comparisons can only be made when cost scenarios are aligned.

\footnotetext{
${ }^{11}$ System cost categories in this report differ from previously published material, beyond inflation adjustments, to delineate profit from overhead for installers and integrators. Also, profit is added to the Q1 2015 commercial benchmark price; thus, it is $\$ 0.06 / \mathrm{W}$ higher than in the 2015 publication $(\$ 0.05 / \mathrm{W}$ profit; $\$ 0.01 / \mathrm{W}$ inflation).

${ }^{12}$ Soft cost $=$ total cost - hardware (module, inverter, structural and electrical BOS) cost.

${ }^{13}$ An increasing soft cost proportion in Figure 26 indicates soft costs declined more slowly than hardware costs; it does not indicate soft costs increased on an absolute basis.
} 


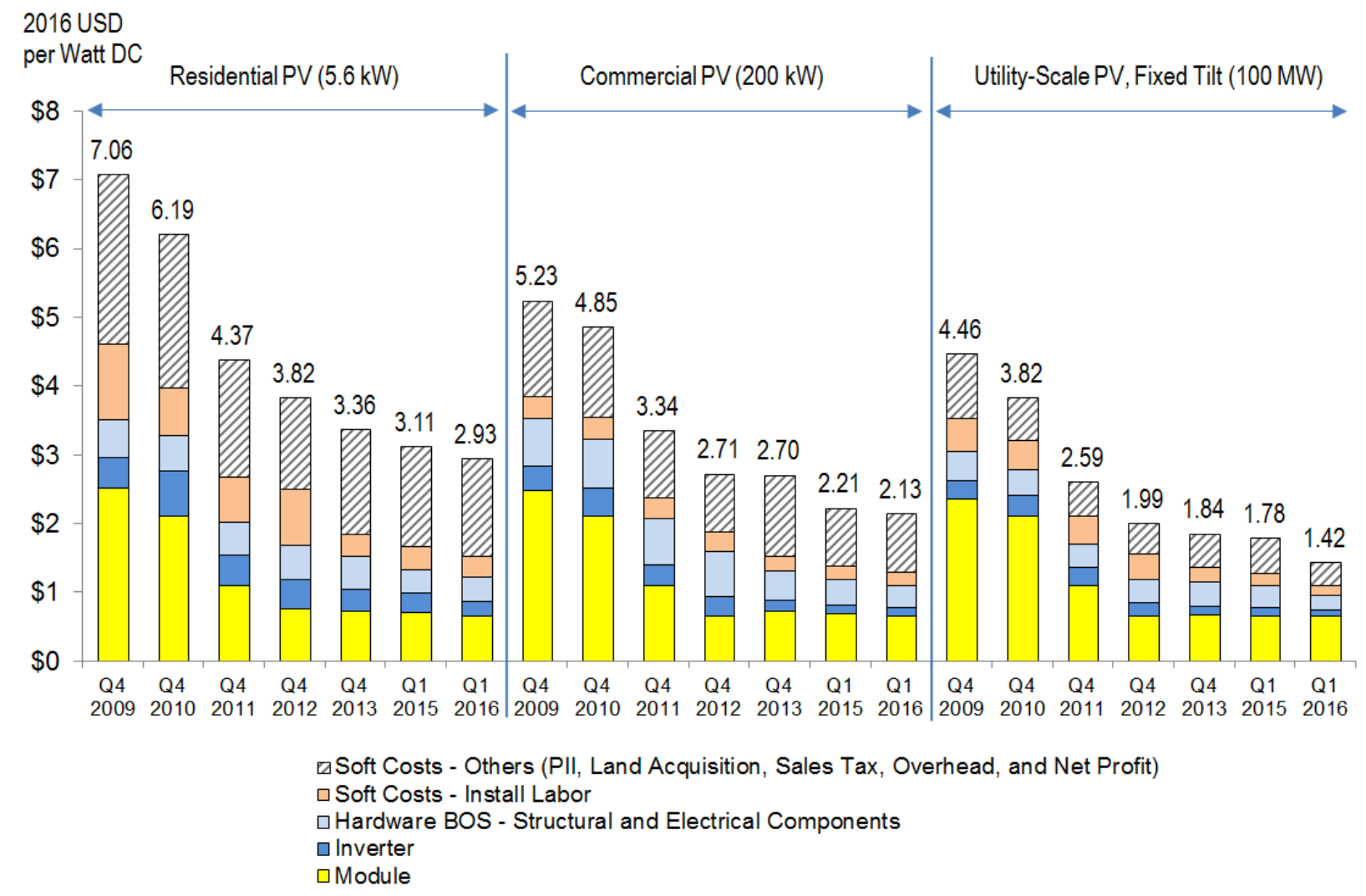

Figure 25. NREL PV system cost benchmark summary (inflation adjusted), Q4 2009-Q1 2016 
Table 6. Q1 2016 NREL PV System Cost Benchmark Change (USD/Wdc)

\begin{tabular}{|c|c|c|c|c|}
\hline Sector & $\begin{array}{l}\text { (1) Difference from } \\
\text { Q1 } 2015 \text { to Q1 } 2016 \\
\text { (\$2016/Wdc) } \\
(1)=(2)+(3)\end{array}$ & $\begin{array}{l}\text { (2) Year-to-Year } \\
\text { Nominal Cost } \\
\text { Decline }\end{array}$ & $\begin{array}{l}\text { (3) Inflation } \\
\text { Impact }\end{array}$ & $\begin{array}{l}\text { Major Model Changes } \\
\text { for Q1 } 2016\end{array}$ \\
\hline Residential & $\$ 0.17$ & $\$ 0.15$ & $\$ 0.02$ & $\begin{array}{l}\text { More inverter options } \\
\text { added }\end{array}$ \\
\hline Commercial & $\$ 0.08$ & $\$ 0.07$ & $\$ 0.01$ & (see Footnote 11) \\
\hline $\begin{array}{l}\text { Utility-Scale } \\
\text { (fixed-tilt) }\end{array}$ & $\$ 0.35$ & $\begin{array}{l}\$ 0.33 \\
=\$ 0.08 \text { (actual cost } \\
\text { decline before } \\
\text { model change) } \\
+\$ 0.12 \text { (EPC cost } \\
\text { decline after model } \\
\text { change) } \\
+\$ 0.13 \text { (developer } \\
\text { cost decline after } \\
\text { model change) }\end{array}$ & $\$ 0.02$ & $\begin{array}{l}\text { More aggressive } \\
\text { economies of scale } \\
\text { applied on EPC and } \\
\text { developer costs to reflect } \\
\text { labor productivity, } \\
\text { construction logistics, } \\
\text { bulk price, and } \\
\text { discounted developer } \\
\text { overhead for larger } \\
\text { systems }\end{array}$ \\
\hline
\end{tabular}

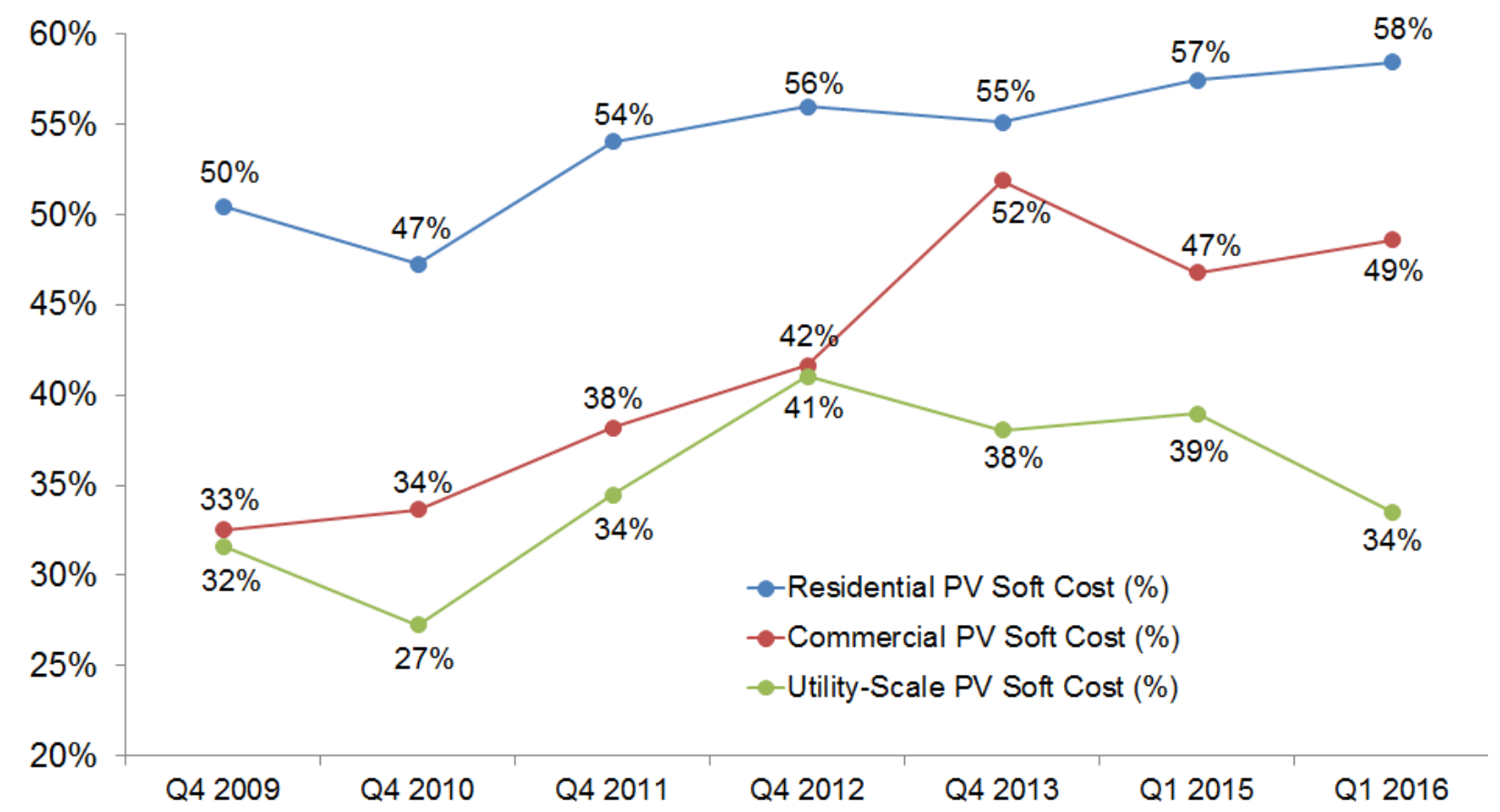

Figure 26. Modeled trend of soft cost as a proportion of total cost by sector, Q4 2009-Q1 2016 


\section{References}

Ardani, Kristen, and Robert Margolis. 2015. Decreasing Soft Costs for Solar Photovoltaics by Improving the Interconnection Process: A Case Study of Pacific Gas and Electric. Golden, CO: National Renewable Energy Laboratory. NREL/TP-7A4065066. http://www.nrel.gov/docs/fy15osti/65066.pdf.

ASCE (American Society of Civil Engineers). 2006. Minimum Design Loads for Buildings and Other Structures (7-05). Reston, VA: American Society of Civil Engineers.

Barbose, Galen, and Naïm Darghouth. 2015. Tracking the Sun VIII: The Installed Price of Residential and Non-Residential Photovoltaic Systems in the United States. Berkeley, CA: Lawrence Berkeley National Laboratory. https://emp.lbl.gov/publications/tracking-sun-viiiinstalled-price.

Bloomberg. 2016. Bloomberg Professional service. Accessed May 20 from NREL.

BLS (U.S. Bureau of Labor Statistics). 2016. "Occupational Employment Statistics.” Accessed May 8. http://www.bls.gov/oes/tables.htm.

Bolinger, Mark, and Joachim Seel. 2015. Utility-Scale Solar 2014: An Empirical Analysis of Project Cost, Performance, and Pricing Trends in the United States. Berkeley, CA: Lawrence Berkeley National Laboratory. https://emp.lbl.gov/publications/utility-scale-solar-2014empirical.

Case, Tyler. 2012. "US Cost of Doing Business: Costs Fall in 2010.” Moody's Analytics Regional Financial Review, September 2012.

Chung, Donald, Carolyn Davidson, Ran Fu, Kristen Ardani, and Robert Margolis. 2015. U.S. Photovoltaic Prices and Cost Breakdowns: Q1 2015 Benchmarks for Residential, Commercial, and Utility-Scale Systems. Golden, CO: National Renewable Energy Laboratory. NREL/TP6A20-64746. http://www.nrel.gov/docs/fy15osti/64746.pdf.

CSI (California Solar Initiative). 2016. “CSI Working Data Set.” Accessed May

10. https://www.californiasolarstatistics.ca.gov/data downloads/.

DSIRE (Database of State Incentives for Renewables \& Efficiency). 2016. Accessed May 10. http://www.dsireusa.org/.

Enphase. 2016. Enphase quarterly presentations. Accessed June 20. http://investor.enphase.com/events.cfm? Year=2015.

Feldman, David, Galen Barbose, Robert Margolis, Mark Bolinger, Donald Chung, Ran Fu, Joachim Seel, Carolyn Davidson, Naïm Darghouth, and Ryan Wiser. 2015. Photovoltaic System Pricing Trends, Historical, Recent, and Near-Term Projections. Golden, CO: National Renewable Energy Laboratory. NREL/PR-6A2064898. http://www.nrel.gov/docs/fy15osti/64898.pdf. 
Feldman, David, Barry Friedman, and Robert Margolis. 2013. Financing, Overhead, and Profit: An In-Depth Discussion of Costs Associated with Third-Party Financing of Residential and Commercial Photovoltaic Systems. Golden, CO: National Renewable Energy Laboratory. NREL/TP-6A20-60401. http://www.nrel.gov/docs/fy14osti/60401.pdf.

Fu, Ran, Ted L. James, Donald Chung, Douglas Gagne, Anthony Lopez, and Aron Dobos. 2015a. "Economic Competitiveness of U.S. Utility-Scale Photovoltaic Systems in 2015: Regional Cost Modeling of Installed Cost $(\$ / \mathrm{W})$ and LCOE $(\$ / \mathrm{kWh})$." Presented at the IEEE 42nd Photovoltaic Specialist Conference, New Orleans,

LA. http://www.nrel.gov/analysis/pdfs/Economic_Competitiveness_of_US UtilityScale_Photovoltaics_System.pdf.

Fu, Ran, Ted L. James, and Michael Woodhouse. 2015b. "Economic Measurements of Polysilicon for the Photovoltaic Industry: Market Competition and Manufacturing Competitiveness." IEEE Journal of Photovoltaics 5:515-524.

Go Solar CA (Go Solar California). 2016. "Currently Interconnected Data Set." Accessed May 10. https://www.californiasolarstatistics.ca.gov/data_downloads/.

GTM Research. 2015. Q3 2015 Solar Executive Briefing. Boston: Greentech Media.

GTM Research and SEIA (Solar Energy Industries Association). 2016. U.S. Solar Market Insight Report, Q1 2016. Washington, DC: Solar Energy Industries Association.

Mints, Paula. 2016. Photovoltaic Manufacturer Capacity, Shipments, Price \& Revenues 2015/2016. San Francisco: Solar PV Market Research.

NREL. 2016. NREL dialogues and interviews with solar industry collaborators. Golden, CO: National Renewable Energy Laboratory.

PVinsights. 2016. PVinsights database. Accessed May 20 from NREL.

RSMeans, ed. 2015. RSMeans Building Construction Cost Data 2015, 73rd annual edition. Norwell, MA: RSMeans.

SEPA (Smart Electric Power Alliance). 2016. "2015 Utility Solar Market Snapshot.” Accessed August 22. https://www.solarelectricpower.org/about-sepa/sepa-news/press-releases/sepa-issues2015-solar-market-snapshot.aspx.

SolarCity. 2016. SolarCity quarterly presentations. Accessed June 20. http://investors.solarcity.com/events.cfm.

SolarEdge. 2016. SolarEdge quarterly presentations. Accessed June 20. http://investors.solaredge.com/phoenix.zhtml? $\mathrm{c}=253935 \& \mathrm{p}=$ irol-news\&nyo $=0$.

Sunrun. 2016. Sunrun quarterly presentations. Accessed June 20. http://investors.sunrun.com/phoenix.zhtml?c=254007\&p=irol-calendar. 
Vivint Solar. 2016. Vivint Solar quarterly presentations. Accessed June 20. http://investors.vivintsolar.com/company/investors/events-andpresentations/presentations/default.aspx.

Vote Solar. 2015. "Project Permit.” Accessed July 8. http://projectpermit.org/2013/02/06/bestpractices/.

Vote Solar and IREC (Interstate Renewable Energy Council). 2013. Project Permit: Best Practices in Residential Solar Permitting. San Francisco: Vote Solar Initiative.

XE Currency Charts. 2016. Historical currency conversion. Accessed May

2. http://www.xe.com/currencycharts/. 